\title{
Interaction of DNA demethylase and histone methyltransferase upregulates Nrf2 in 5-fluorouracil-resistant colon cancer cells
}

\author{
Kyoung Ah Kang ${ }^{1}$, Mei Jing Piao${ }^{1}$, Yea Seong Ryu ${ }^{1}$, Hee Kyoung Kang ${ }^{1}$, Weon Young \\ Chang ${ }^{1}$, Young Sam Keum ${ }^{2}$, Jin Won Hyun ${ }^{1}$ \\ ${ }^{1}$ School of Medicine, Jeju National University, Jeju 63243, Republic of Korea \\ ${ }^{2}$ Department of Biochemistry, College of Pharmacy, Dongguk University, Goyang 10326, Republic of Korea \\ Correspondence to: Jin Won Hyun, email: jinwonh@jejunu.ac.kr \\ Keywords: Nrf2 transcription factor, DNA demethylase, histone methyltransferase, 5-fluorouracil-resistance, oxidative stress \\ Received: January 15, 2016 \\ Accepted: May 09, 2016 \\ Published: May 31, 2016
}

\section{ABSTRACT}

We recently reported that DNA demethylase ten-eleven translocation 1 (TET1) upregulates nuclear factor erythroid 2-related factor 2 ( Nrf2) in 5-fluorouracilresistant colon cancer cells (SNUC5/5-FUR). In the present study, we examined the effect of histone modifications on Nrf2 transcriptional activation. Histone deacetylase (HDAC) and histone acetyltransferase (HAT) were respectively decreased and increased in SNUC5/5-FUR cells as compared to non-resistant parent cells. Mixedlineage leukemia (MLL), a histone methyltransferase, was upregulated, leading to increased trimethylation of histone $\mathrm{H3}$ lysine 4, while G9a was downregulated, leading to decreased dimethylation of histone H3 lysine 9. siRNA-mediated MLL knockdown decreased levels of Nrf2 and HO-1 to a greater extent than did silencing HAT1. Host cell factor 1 (HCF1) was upregulated in SNUC5/5-FUR cells, and we observed interaction between HCF1 and MLL. Upregulation of O-GICNAc transferase (OGT), an activator of HCF1, was also associated with HCF1-MLL interaction. In SNUC5/5-FUR cells, a larger fraction of OGT was bound to TET1, which recruits OGT to the Nrf2 promoter region, than in SNUC5 cells. These findings indicate that SNUC5/5-FUR cells are under oxidative stress, which induces expression of histone methylationrelated proteins as well as DNA demethylase, leading to upregulation of Nrf2 and 5-FU resistance.

\section{INTRODUCTION}

Histone modifications including methylation, acetylation, ubiquitination, and phosphorylation regulate gene expression programs. In particular, the mixed-lineage leukemia (MLL) family of histone methyltransferases regulates gene expression by methylating lysine 4 of histone $\mathrm{H} 3$ (H3K4), which is associated with an active chromatin state [1]. Histone-lysine N-methyltransferase, SET, or MLL acts as the catalytic subunit of the protein complexes associated with the SET/COMPASS complex or MLL/COMPASS-like complex [2]. These subunits aid in complex assembly and recruitment to targets, and modulate the methyltransferase activity of the SET domain-containing subunits [1, 3]. For example, host cell factor 1 (HCF1) is a component of the H3K4 methyltransferase SET/COMPASS complex and is important for its integrity [4].
The ten-eleven translocation (TET) family proteins, including TET1, TET2, and TET3, catabolize the oxidation of 5-methylcytosine to 5-hydroxylmethylcytosine, 5-formylcytosine, and 5-carboxylcytosine, resulting in the formation of cytosine [5]. TET proteins have been implicated in genome-wide DNA methylation control, gene expression regulation, cellular differentiation, and cancer development [6-8].

DNA methylation is generally associated with gene silencing, while DNA demethylation via TET leads to transcriptional activation. Recent studies suggest that the interaction of TET1 with O-GlcNAc transferase (OGT) stabilizes TET1 binding to target promoters $[6,9]$. Genomewide localization analyses show enrichment of TET1 on regulatory regions marked by $\mathrm{H} 3 \mathrm{~K} 4$ trimethylation (H3K4Me3) [10, 11]. Furthermore, TET2 and TET3 regulate GlcNAcylation and $\mathrm{H} 3 \mathrm{~K} 4$ methylation through OGT and SET/COMPASS [4]. This suggests that in 
addition to its role in reducing DNA methylation, the TETOGT interaction recruits proteins required to establish a high $\mathrm{H} 3 \mathrm{~K} 4 \mathrm{Me} 3$ chromatin environment

Oxidative stress is involved in most chronic diseases including cancer. Interestingly, epigenetic modification of DNA and histones is modulated by oxidative stress [12]. Recently, we reported that nuclear factor erythroid 2-related factor 2 (Nrf2), a major transcription factor for antioxidant enzymes, is highly expressed in 5-fluorouracil (5-FU)-resistant cells under oxidative stress through the DNA demethylating function of TET1 [13].

In the present study, we aimed to determine whether histone methyl-modifications are involved in the modulation of Nrf2 expression in 5-FU-resistant cells and the role of TET1 in histone methyl-modifications. This report is the first to examine the relationship between histone methyltransferase and DNA demethylase and modulation of Nrf2 expression.

\section{RESULTS}

\section{Expression of Nrf2 in chemo-resistant cancer cells}

Previously, we reported that Nrf2 expression was higher in 5-FU-resistant colon cancer cells (SNUC5/5FUR) than parent colon cancer cells (SNUC5) [14]. Here, in addition to SNUC5/5-FUR, we determined that Nrf2 expression was higher in oxaliplatin resistant SNUC5 cells (SNUC5/OXTR) and cisplatin resistant ovarian cancer cells (A2780/CR) than in parental SNUC5 and A2780 cells, respectively (Figure 1). These data link Nrf2 to chemo-resistance in cancer cells, and led us to select SNUC5/5-FUR cells for further study.

\section{Expression of histone modification-related proteins in SNUC5 and SNUC5/5-FUR cells}

As TET-dependent DNA demethylation upregulated Nrf2 expression in SNUC5/5-FUR cells, we investigated the expression levels of histone acetylation- and methylation-related proteins in SNUC5 and SNUC5/5FUR cells. HDAC1 expression was decreased and HAT1 expression was increased in SNUC5/5-FUR cells compared to SNUC5 cells, resulting in increased H3K9 acetylation (H3K9Ac) (Figure 2A). In addition to histone acetylation, histone methyltransferase MLL and trimethylation of its target protein $\mathrm{H} 3 \mathrm{~K} 4$ (H3K4Me3) were increased in SNUC5/5-FUR cells compared to SNUC5 cells, while histone methyltransferase G9a and dimethylation of its target protein $\mathrm{H} 3 \mathrm{~K} 9$ (H3K9Me2) were decreased in SNUC5/5-FUR cells (Figure 2B). Furthermore, siRNA knockdown of MLL in SNUC5/5FUR cells significantly decreased the expression levels of
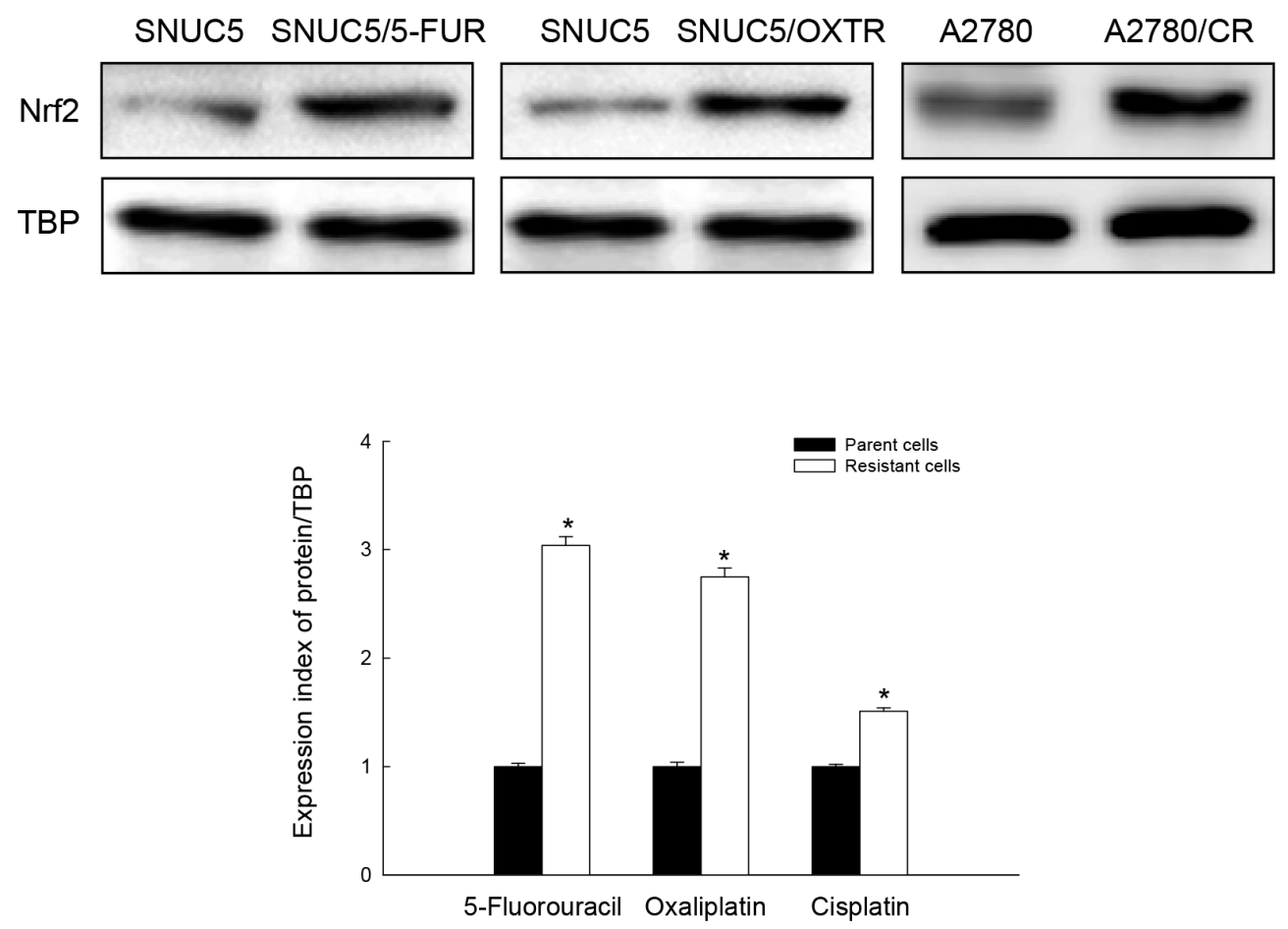

Figure 1: Nrf2 protein level in chemo-resistant cancer cells. The nuclear Nrf2 protein level in SNUC5 and SNUC5/5-FUR, SNUC5 and SNUC5/OXTR, A2780 and A2780/CR were assessed using Western blot analysis. TBP antibody was used as loading control for nuclear fraction. Densito-metric quantification of band intensity was measured and normalized relative to the band intensity of the TBP loading control. *Significantly different from parent cells respectively $(\mathrm{p}<0.05)$. 
Nrf2 and its target protein HO-1. Knockdown of HAT1 resulted in a smaller decrease in $\mathrm{Nrf} 2$ and $\mathrm{HO}-1$ protein expression than MLL knockdown (Figure 2C). These results led us to focus on MLL to elucidate the relationship between Nrf2 and histone modifications in SNUC5/5-FUR cells.

\section{A}

\section{SNUC5 SNUC5/5-FUR}

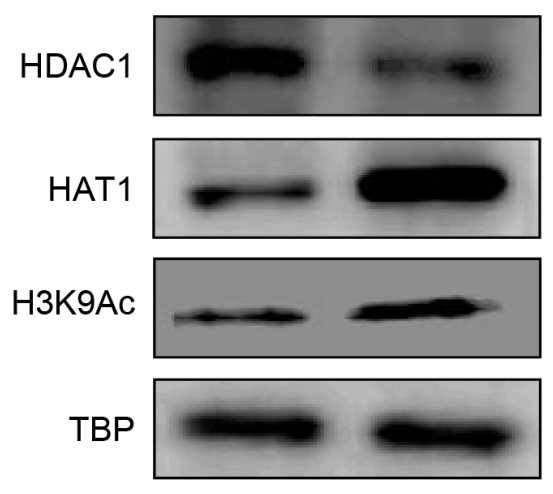

B

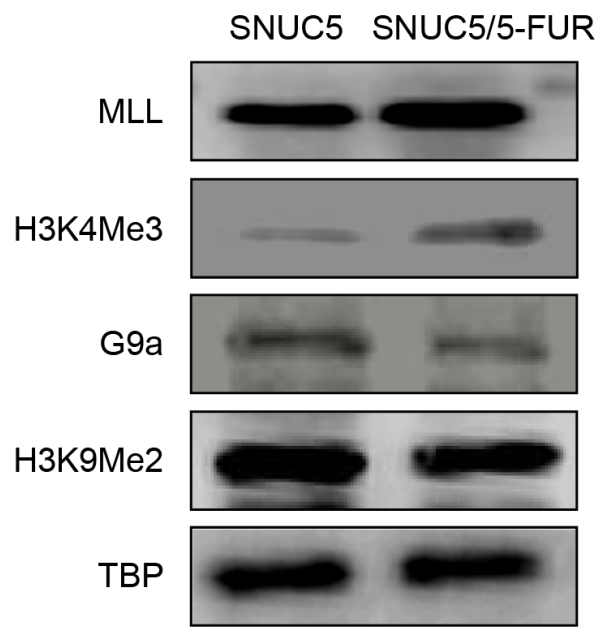

\section{MLL and HCF1 increase Nrf2 expression in SNUC5/5-FUR cells}

Host cell factor 1 (HCF1), a component of the H3K4 methyltransferase SET1(MLL)/COMPASS complex, is crucial for the integrity of the SET1(MLL)/COMPASS
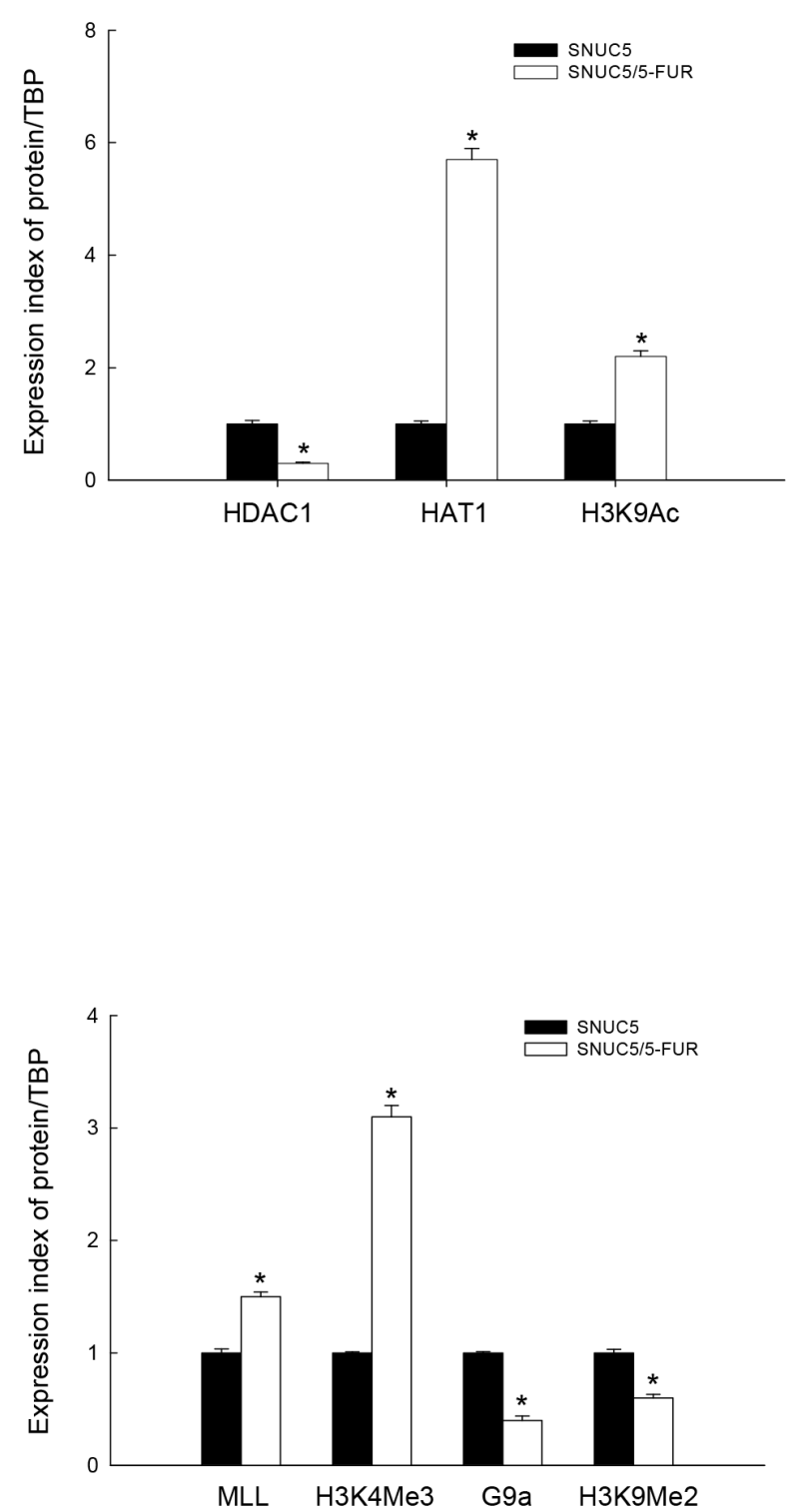

Figure 2: Expression of histone modification-related proteins in SNUC5 and SNUC5/5-FUR. A. Expression patterns of HDAC1, HAT1, and H3K9Ac in SNUC5 and SNUC5/5-FUR cells determined by Western blot analysis. *Significantly different from SNUC5 cells $(\mathrm{p}<0.05)$. B. Expression patterns of MLL, H3K4Me3, G9a, and H3K9Me2 in both cells determined by Western blot analysis. TBP antibody was used as loading control for nuclear fractions. *Significantly different from SNUC5 cells $(p<0.05)$. The cells were transfected with non-targeting siRNA (siControl) or siMLL RNA or siHAT1 RNA for $24 \mathrm{~h}$.

(Continued) 


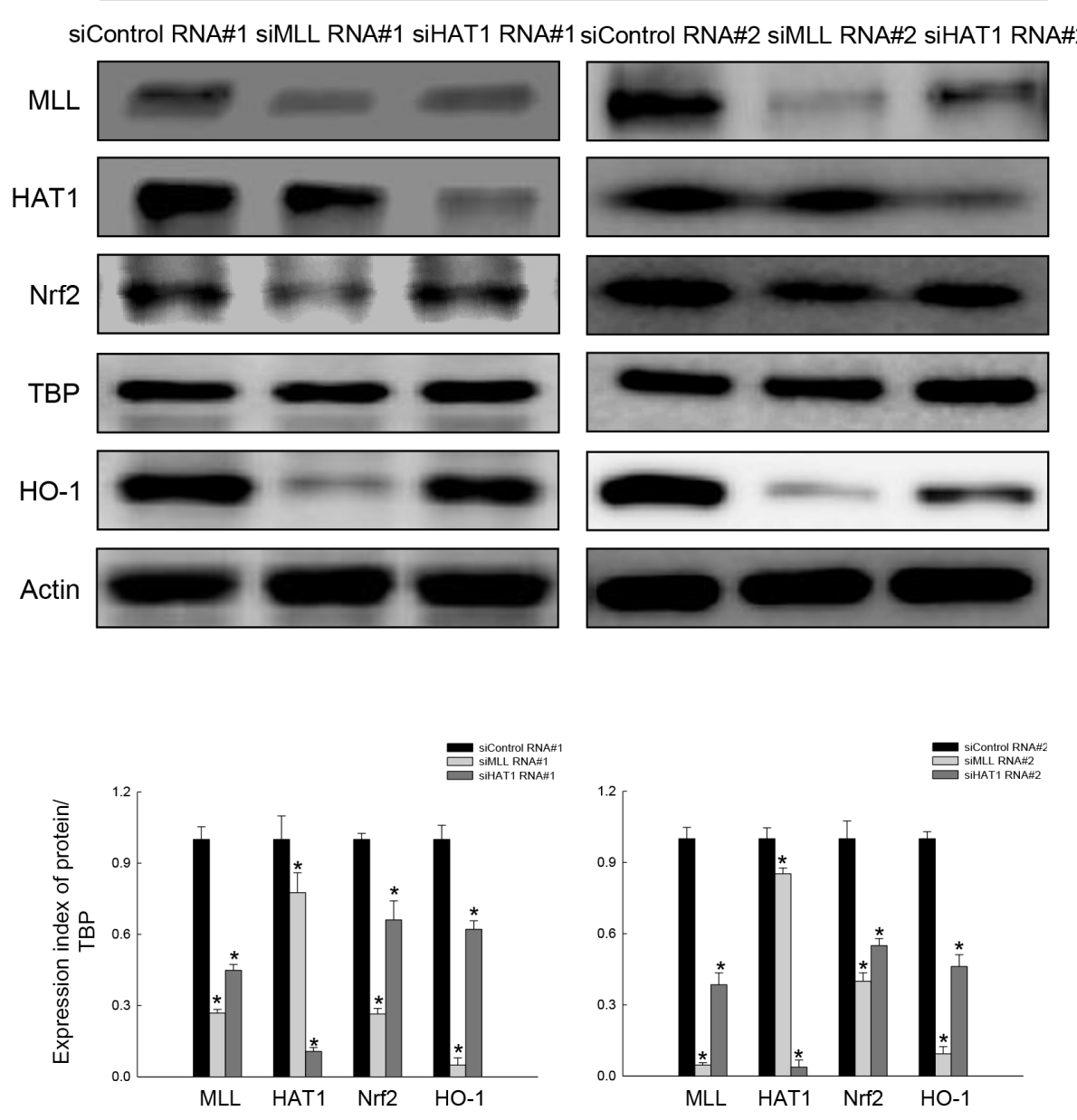

Figure 2 (Continued): C. Expression patterns of MLL, HAT1, Nrf2, and HO-1 in SNUC5/5-FUR determined by Western blot analysis. *Significantly different from untreated siControl-transfected cells $(\mathrm{p}<0.05)$.

complex [4]. HCF1 undergoes a proteolytic maturation process from $\mathrm{HCF} 1_{\text {PRO }}$ (proform for proteolysis), resulting in stable $\mathrm{HCF}_{\mathrm{N}}$ (N-terminal) and $\mathrm{HCF} 1_{\mathrm{C}}(\mathrm{C}$-terminal) subunits [14]. The active form (proteolytic fragments) of HCF1 was increased in SNUC5/5-FUR cells (Figure $3 \mathrm{~A}$ ) and immunoprecipitation (IP) revealed a greater percentage of HCF1 and MLL were found in complex together in SNUC5/5-FUR cells than in SNUC5 cells (Figure 3B). MLL-HCF1 binding measured by proximity ligation assay (PLA) as shown in Figure 3C, was consistent with the IP. A previous study suggested that HCF1 protein functions as a transcriptional switch for the action of MLL [15]. siRNA knockdown of HCF1 led to decreased MLL mRNA and protein in SNUC5/5-FUR cells (Figure 3D and 3E), resulting in decreased Nrf2 protein (Figure 3E). These results suggest that MLL and HCF1 components within the histone methyltransferase,
MLL/COMPASS-like complex, increase Nrf2 expression in SNUC5/5-FUR cells.

\section{OGT increases MLL/COMPASS-like complex- mediated Nrf2 expression}

Recently, Lazarus et al. suggested that HCF1 is GlcNAcylated and undergoes proteolytic maturation in the active site of O-GlcNAc transferase (OGT) [16]. This OGT link is associated with activation of the regulatory functions of HCF1. SNUC5/5-FUR cells showed high levels of OGT and O-GlcNAcylated proteins, suggesting increased OGT function (Figure 4A). A greater percentage of OGT and HCF1 were found in complex together in SNUC5/5-FUR cells than in SNUC5 cells by IP and PLA (Figure 4B and 4C). Also, more MLL-OGT complex was detected in SNUC5/5-FUR cells than in SNUC5 cells 
(Figure 4D and 4E), suggesting all three proteins are in a MLL-OGT-HCF1 complex. Recently, it was reported that MLL protein stability is maintained by OGT; depletion of OGT in cells decreased the MLL protein level through ubiquitin/proteasome-dependent proteolytic degradation, whereas ectopic expression of OGT protein suppressed MLL ubiquitylation [17]. siRNA knockdown of OGT led to decreased mRNA and protein levels of MLL in SNUC5/5-FUR cells, resulting in decreased HCF1 and Nrf2 proteins (Figure 4F and $4 \mathrm{G}$ ).

A

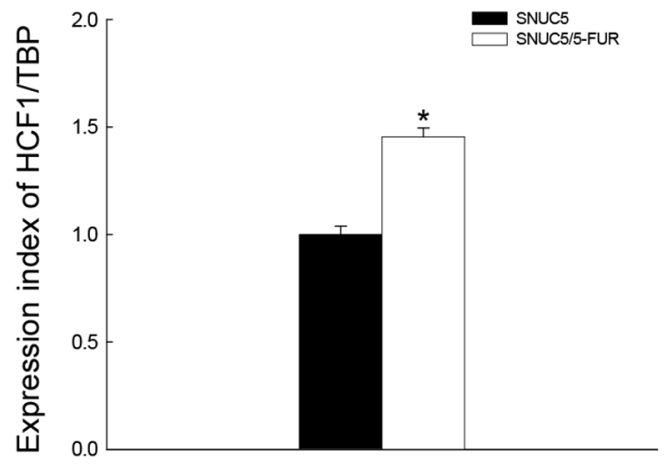

B

IP: MLL

\section{SNUC5 SNUC5/5-FUR}

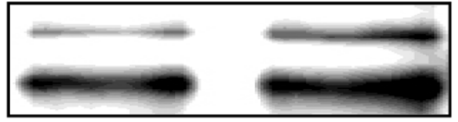

WB:MLL

WB:HCF1 Proteolytic
fragments
SNUC5 SNUC5/5-FUR

$\mathrm{HCF} 1$

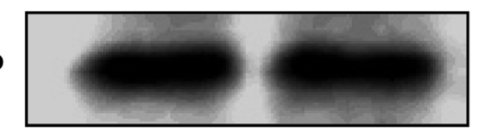

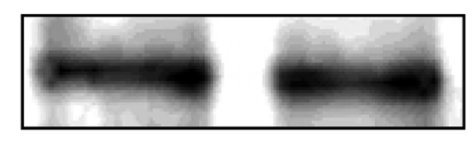

IP: HCF1
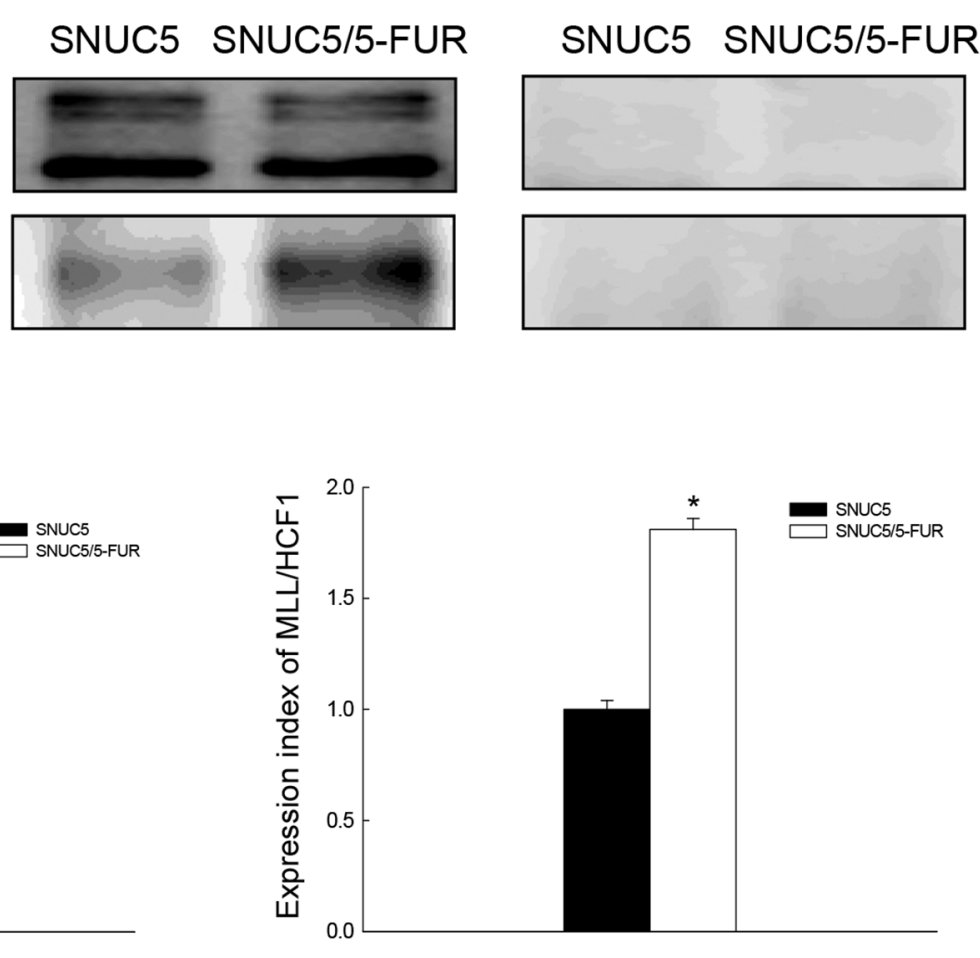

IP: IgG

\section{SNUC5 SNUC5/5-FUR}

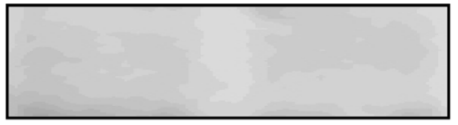

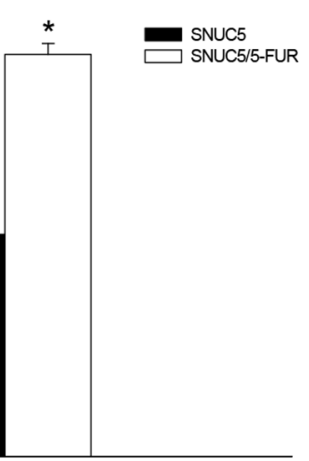

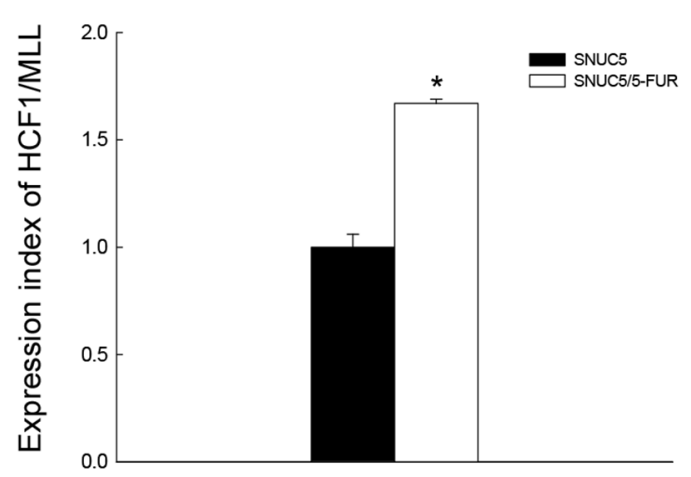

Figure 3: Effect of MLL-HCF1 interaction on histone methylation and Nrf2 expression in SNUC5/5-FUR cells. A. HCF1 expression was determined by Western blotting. *Significantly different from SNUC5 cells $(\mathrm{p}<0.05)$. B. Interaction between MLL and HCF1was examined by immunoprecipitation analysis using anti-MLL and anti-HCF1 antibodies followed by Western blotting with anti-HCF1 and anti-MLL antibodies. *Significantly different from SNUC5 cells $(\mathrm{p}<0.05)$.

(Continued) 


\section{C}
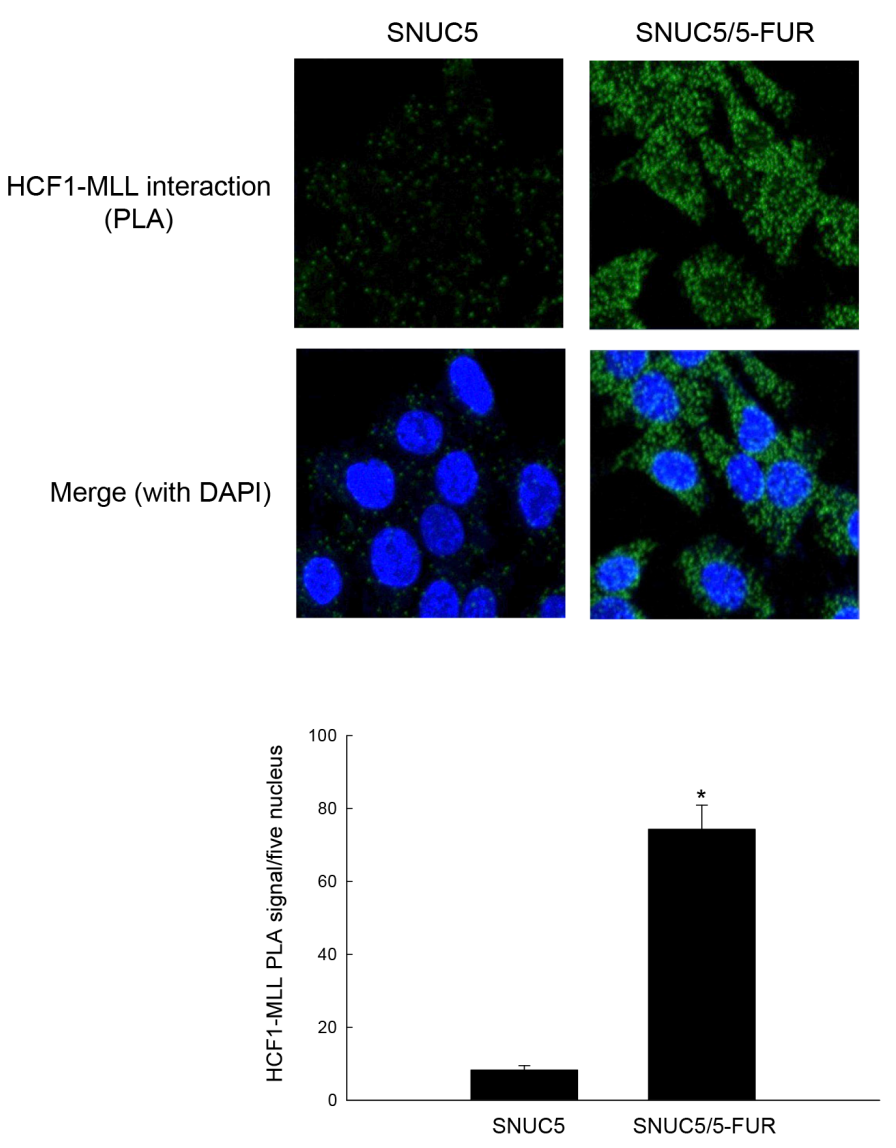

D
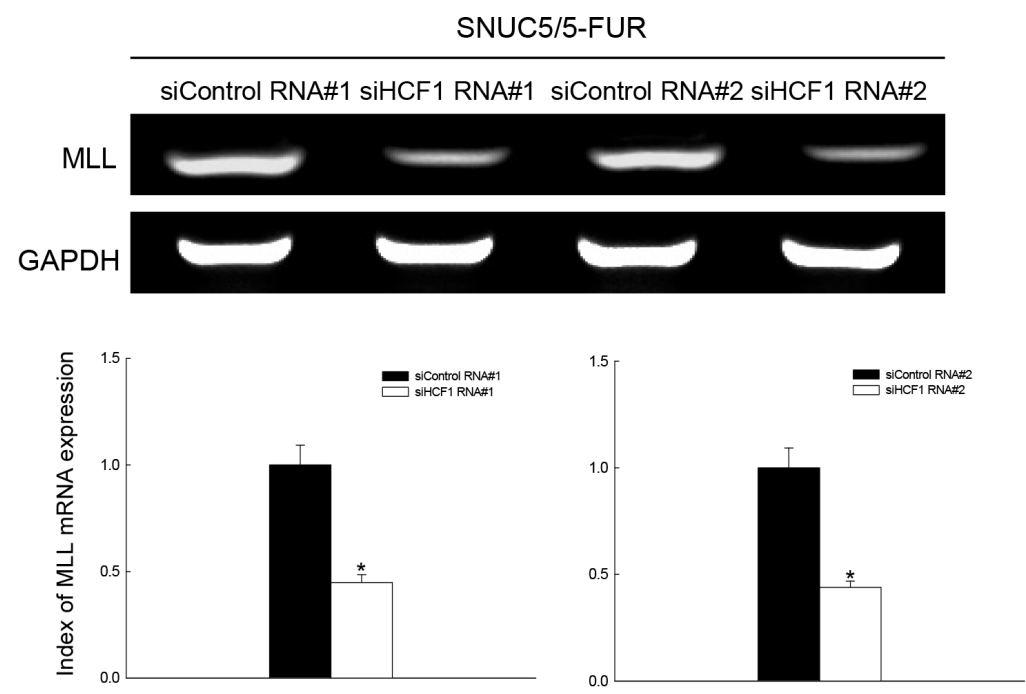

Figure 3 (Continued): C. Interaction between MLL and HCF1 was assessed by PLA. Each green spot represents for a single interaction (MLL and HCF1) and DNA was stained with DAPI. *Significantly different from SNUC5 cells $(\mathrm{p}<0.05)$. The cells were transfected with non-targeting siRNA (siControl) or siHCF1 RNA for $24 \mathrm{~h}$. D. Expression pattern of MLL mRNA in SNUC5/5-FUR cells was determined by RT-PCR analysis. *Significantly different from siControl-transfected cells $(\mathrm{p}<0.05)$.

(Continued) 

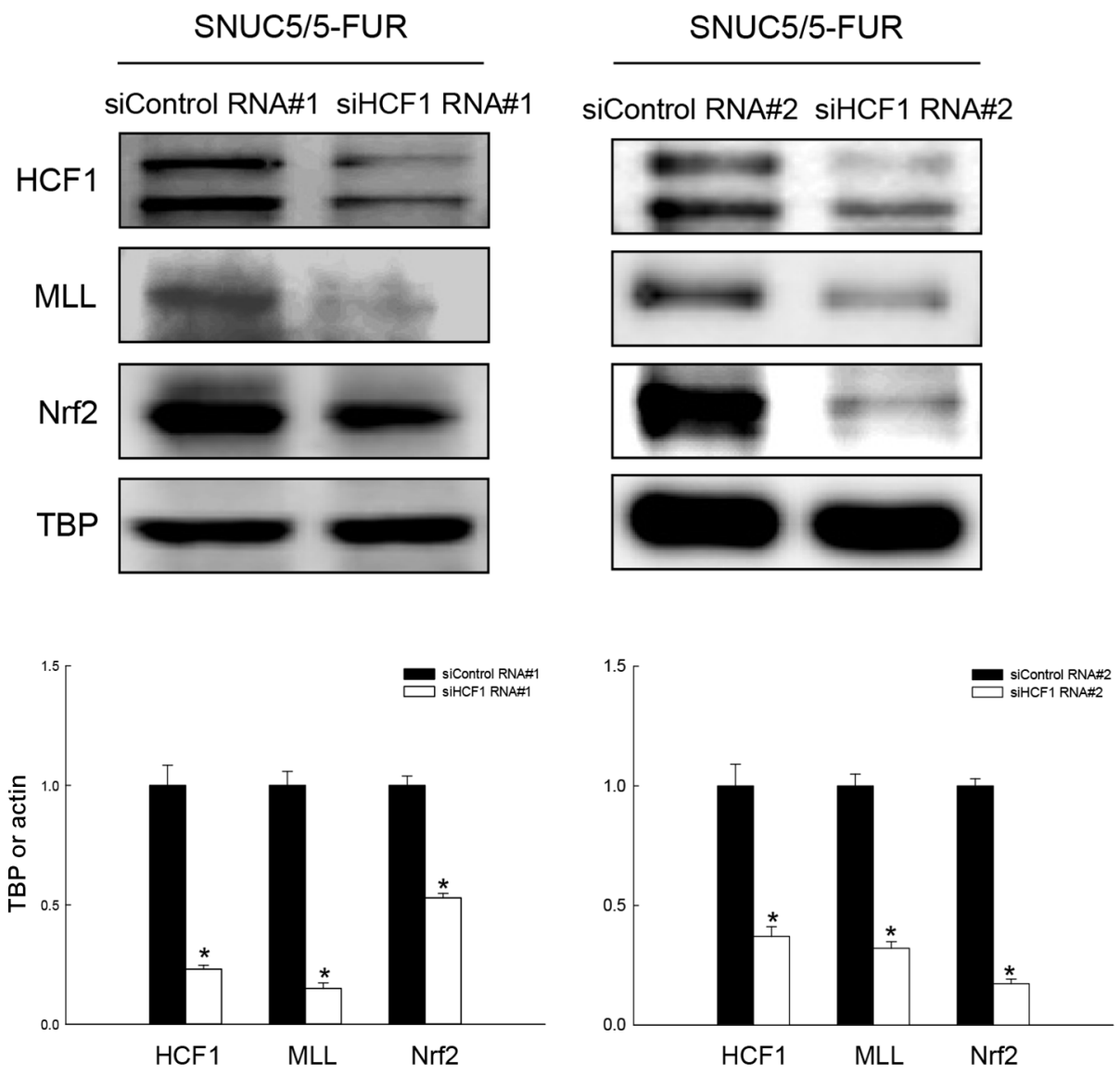

Figure 3 (Continued): E. Expression pattern of HCF1, MLL, and Nrf2 in SNUC5/5-FUR cells was determined by Western blot analysis. *Significantly different from siControl-transfected cells $(\mathrm{p}<0.05)$.

\section{TET1-OGT interaction increases Nrf2 expression}

Recently it was reported that TET-OGT interaction promotes GlcNAcylation and influences $\mathrm{H} 3 \mathrm{~K} 4 \mathrm{Me} 3$ via histone methyltransferase SET1 (MLL)/COMPASS complex resulting in transcriptional activation [4]. TET1 and OGT form a more stable complex in SNUC5/5FUR cells than in SNUC5 cells as determined by IP and PLA (Figure 5A and 5B). TET1 GlcNAcylation status was measured using anti-O-GlcNAc antibody. TET1 was detected by Western blot in anti-GlcNAc immunoprecipitates as was OGT because OGT is self GlcNAcylated [6] (Figure 5C). This result suggests that TET1 is associated with OGT in SNUC5/5-FUR cells and is modified by OGT to become GlcNAcylated. To investigate the significance of the TET1-OGT interaction on Nrf2 expression, we knocked down OGT with siRNA oligonucleotides in SNUC5/5-FUR cells. Knockdown of
OGT decreased TET1 protein (Figure 5D). Furthermore, knockdown of TET1 led to decreased OGT, HCF1, MLL, and Nrf2 protein in SNUC5/5-FUR cells (Figure 5E). These results suggest that the interaction of TET and OGT is necessary for Nrf2 expression in SNUC5/5-FUR cells.

\section{TET1- MLL complex increases H3K4Me3 binding to the Nrf2 promoter}

Because TET1 knockdown decreased MLL in SNUC5/5-FUR cells (Figure 5E), we assessed whether TET1 interacts with MLL. Immunoprecipitation and PLA revealed that the binding between TET1 and MLL was greater in SNUC5/5-FUR cells than in SNUC5 cells (Figure 6A and 6B). To elucidate whether Nrf2 upregulation is directly induced by the epigenetic modifications, chromatin immunoprecipitation (ChIP) assay was used to quantify the $\mathrm{H} 3 \mathrm{~K} 4 \mathrm{Me} 3$ binding to the Nrf2 promoter. As shown in Figure 6C, H3K4Me3 
A
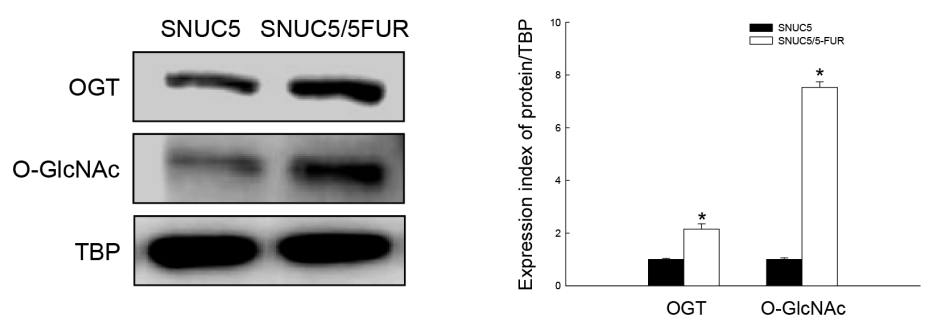

B

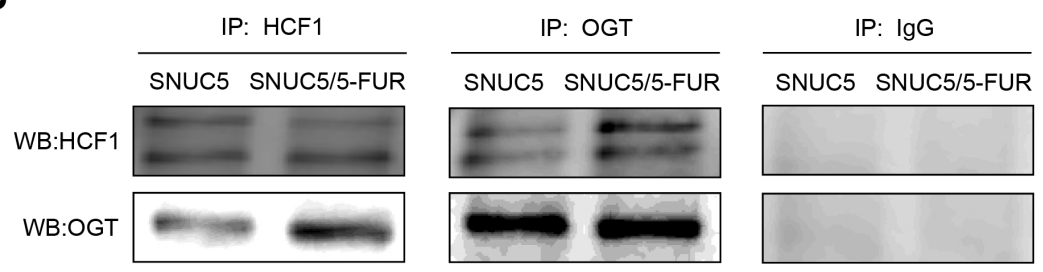

C
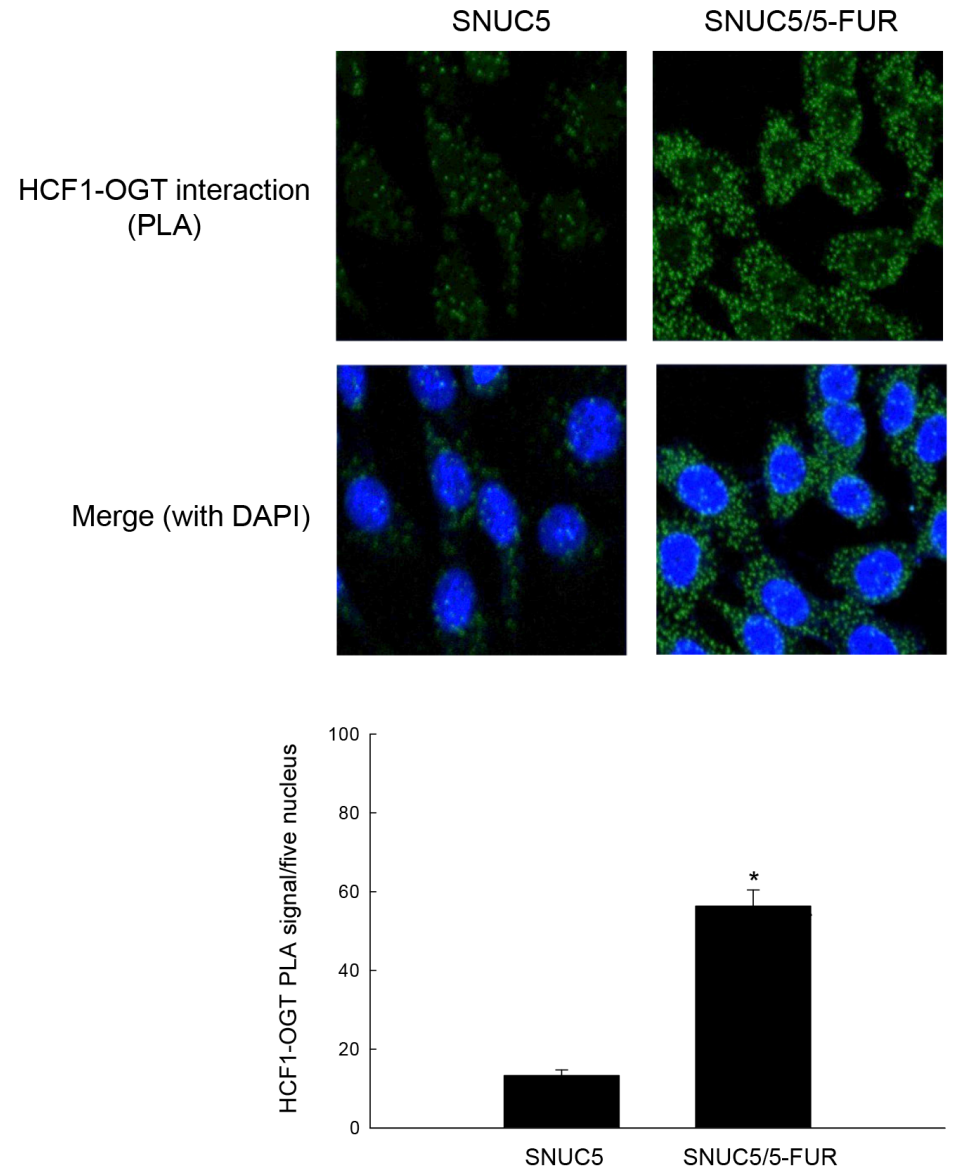

Figure 4: Involvement of OGT in histone methylase MLL/COMPASS-like complex-mediated Nrf2 expression in SNUC5/5-FUR cells. A. OGT and O-GlcNAc expression was determined by Western blotting. *Significantly different from SNUC5 cells $(\mathrm{p}<0.05)$. B. Interaction between HCF1 and OGT was examined by immunoprecipitation analysis using anti-HCF1 and anti-OGT antibodies followed by Western blotting with anti-HCF1 and anti-OGT antibodies. C. Interaction between HCF1 and OGT was assessed by using PLA. Each green spot represents for a single interaction (HCF1 and OGT) and DNA was stained with DAPI. *Significantly different from SNUC5 cells $(\mathrm{p}<0.05)$.

(Continued) 
D

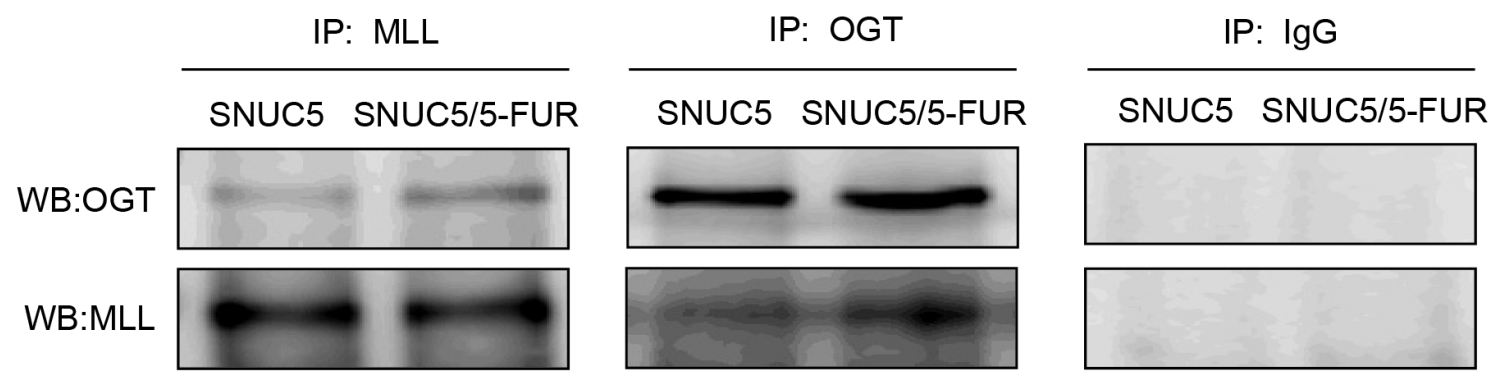

$E$
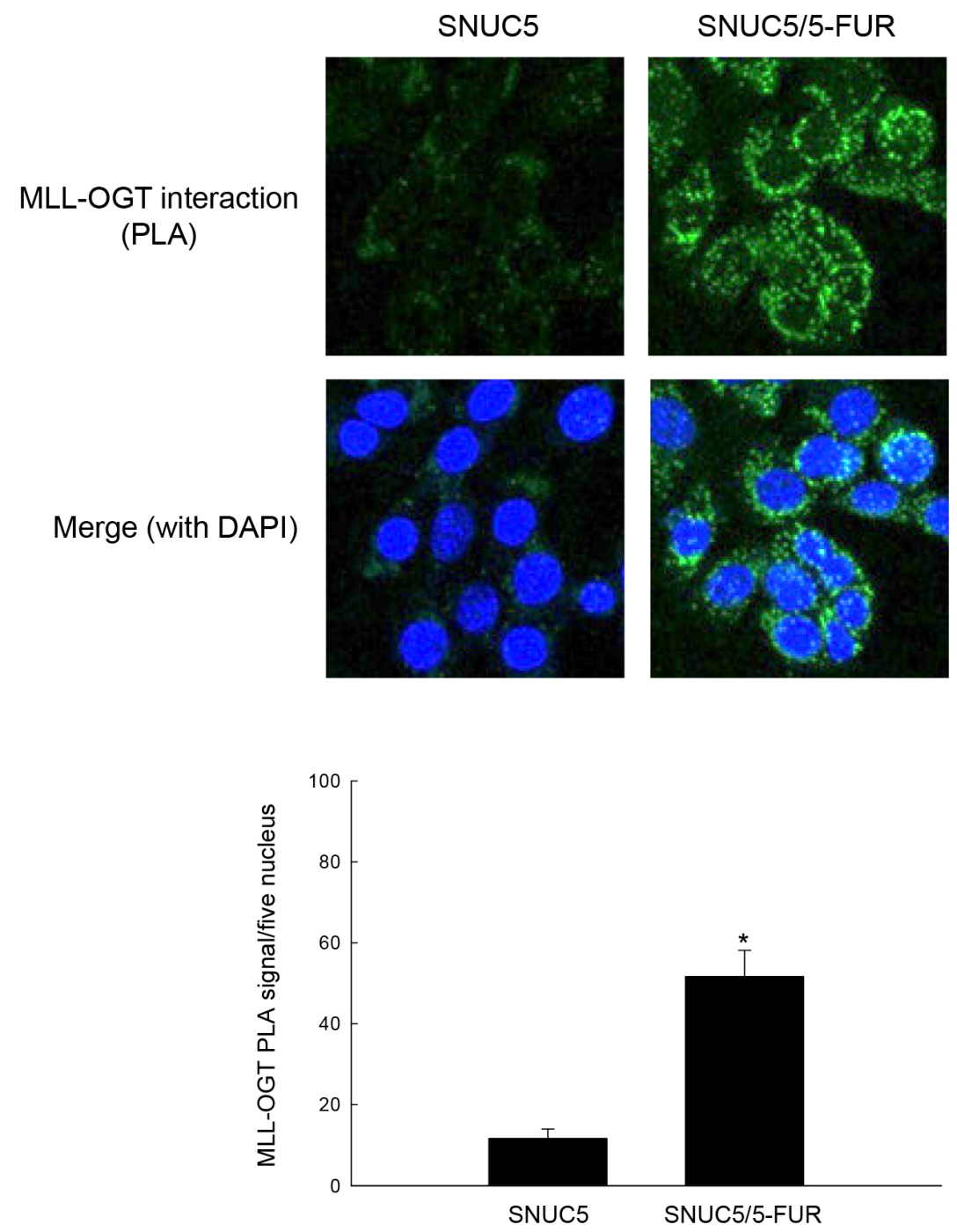

Figure 4 (Continued): D. Interaction between MLL and OGT was examined by immunoprecipitation analysis using anti-MLL and antiOGT antibodies followed by Western blotting with anti-OGT and anti-MLL antibodies. E. Interaction between MLL and OGT was assessed by using PLA. Each green spot represents for a single interaction (MLL and OGT) and DNA was stained with DAPI. *Significantly different from SNUC5 cells $(\mathrm{p}<0.05)$. The cells were transfected with non-targeting siRNA (siControl) or siOGT RNA for $24 \mathrm{~h}$.

(Continued) 
siControl RNA\#1 siOGT RNA\#1 siControl RNA\#2 siOGT RNA\#2

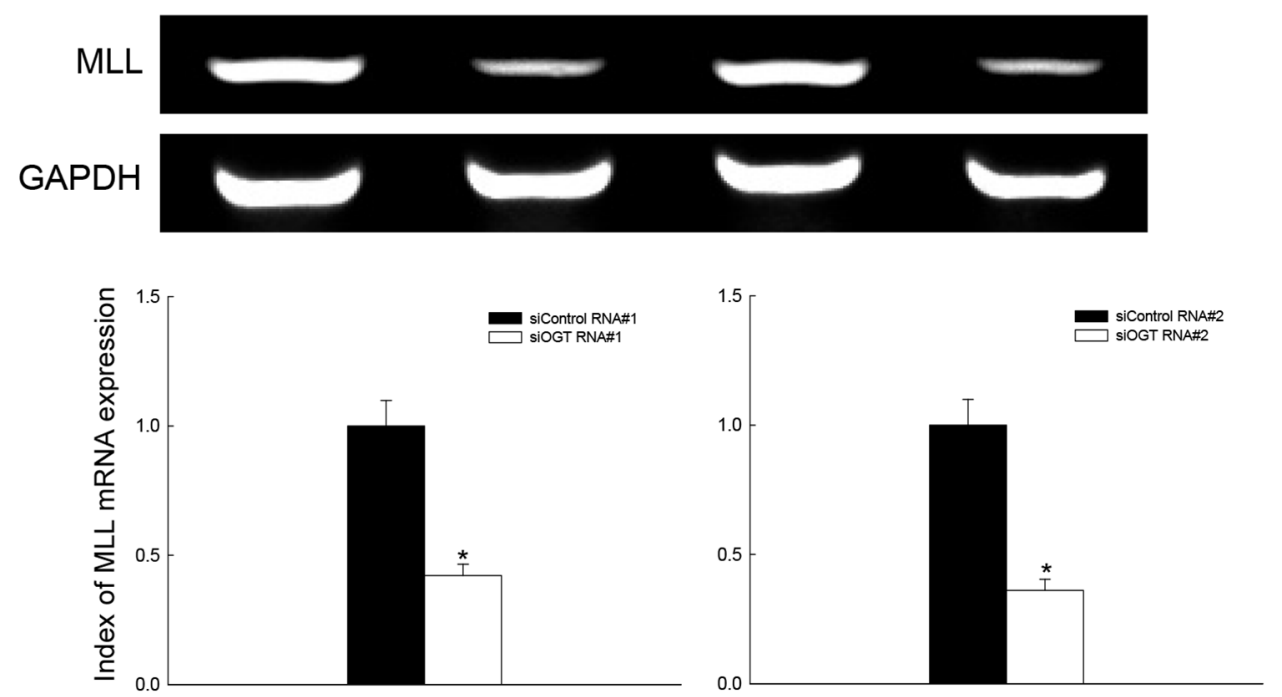

$\mathbf{G}$

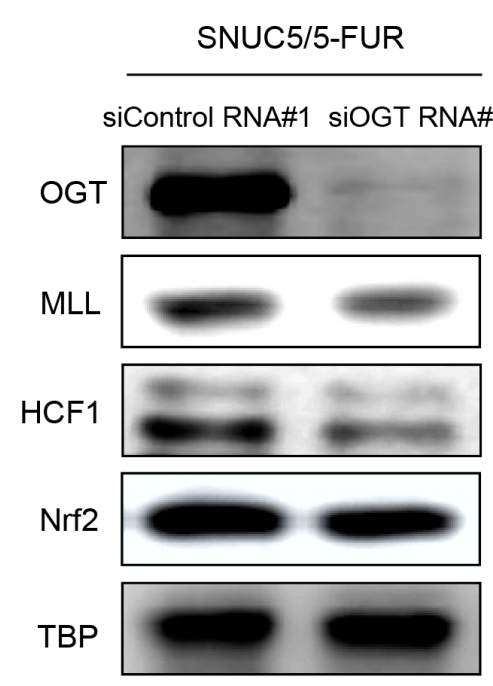

SNUC5/5-FUR

siControl RNA\#2 siOGT RNA\#2
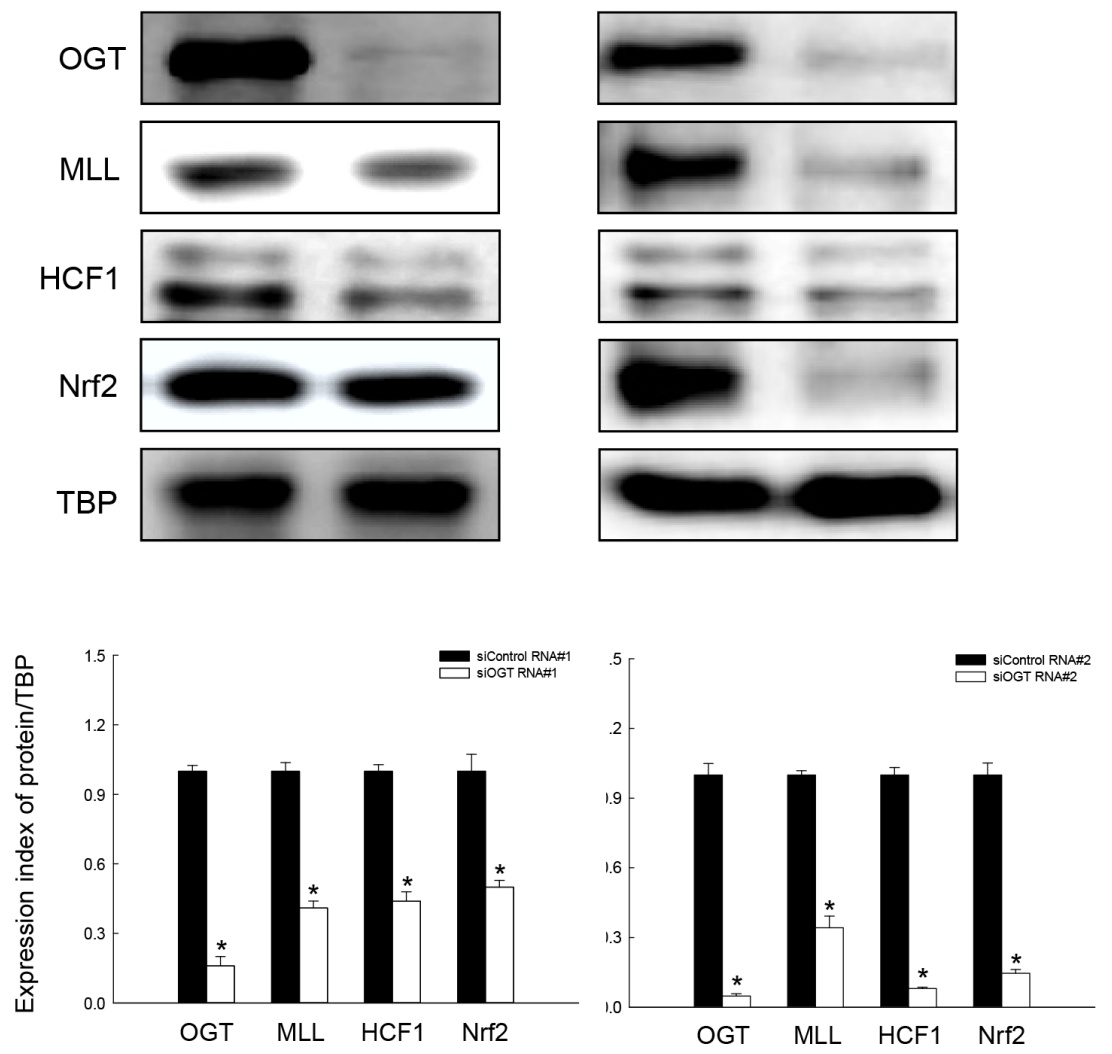

Figure 4 (Continued): F. Expression pattern of MLL mRNA in SNUC5/5-FUR cells was determined by RT-PCR analysis. *Significantly different from siControl-transfected cells $(\mathrm{p}<0.05)$. G. Expression pattern of OGT, MLL, HFC1, and Nrf2 in SNUC5/5-FUR cells was determined by Western blot analysis. *Significantly different from siControl-transfected cells $(\mathrm{p}<0.05)$. 
A

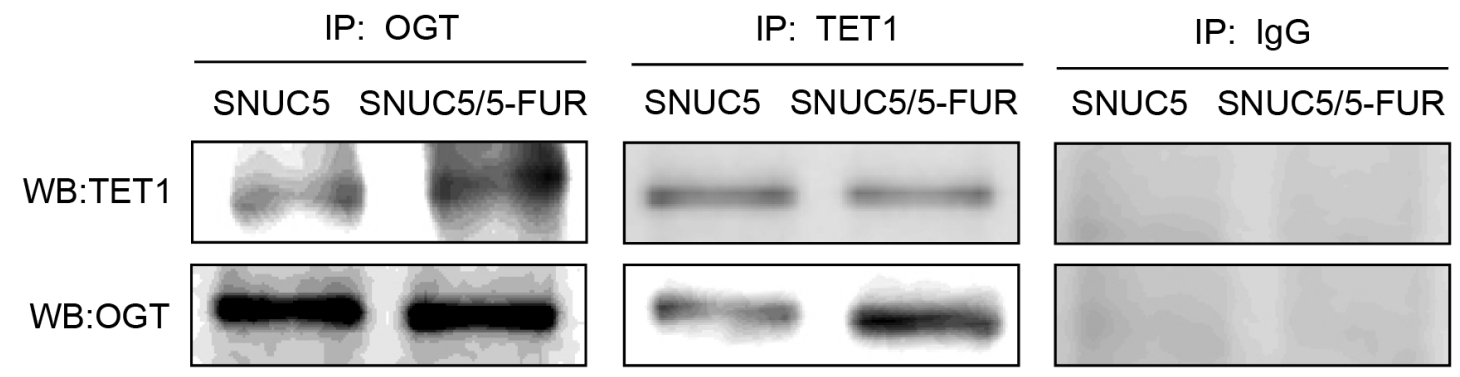

B

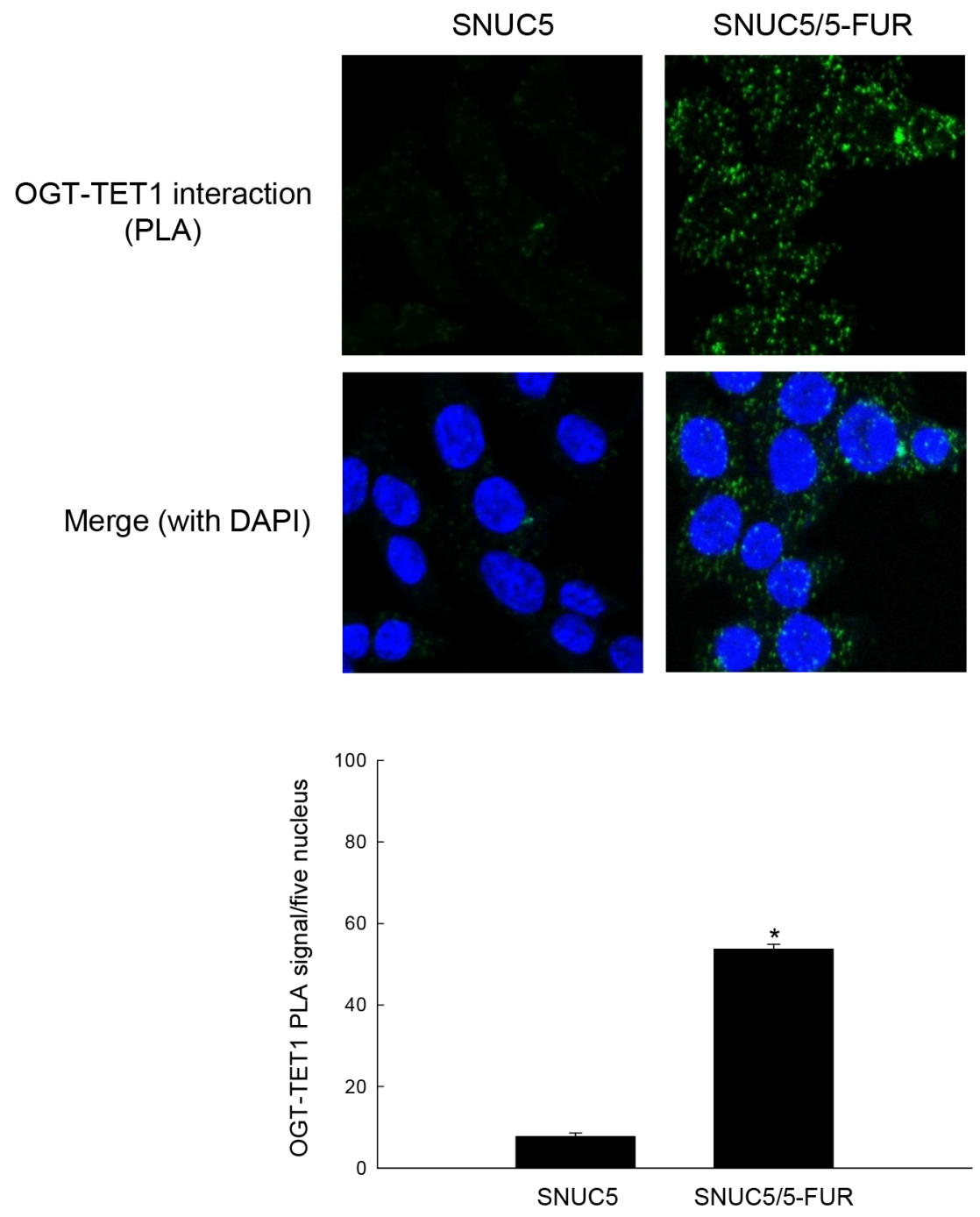

Figure 5: Relation of OGT-TET1 interaction on histone methylation and Nrf2 expression in SNUC5/5-FUR cells. A. Interaction between OGT and TET1 was examined by immunoprecipitation analyses using anti-OGT and anti-TET1 antibodies followed by Western blotting with anti-TET1 and anti-OGT antibodies. B. Interaction between OGT and TET1 was assessed by using PLA. Each green spot represents for a single interaction (OGT and TET1) and DNA was stained with DAPI. *Significantly different from SNUC5 cells $(\mathrm{p}<0.05)$.

(Continued) 
C
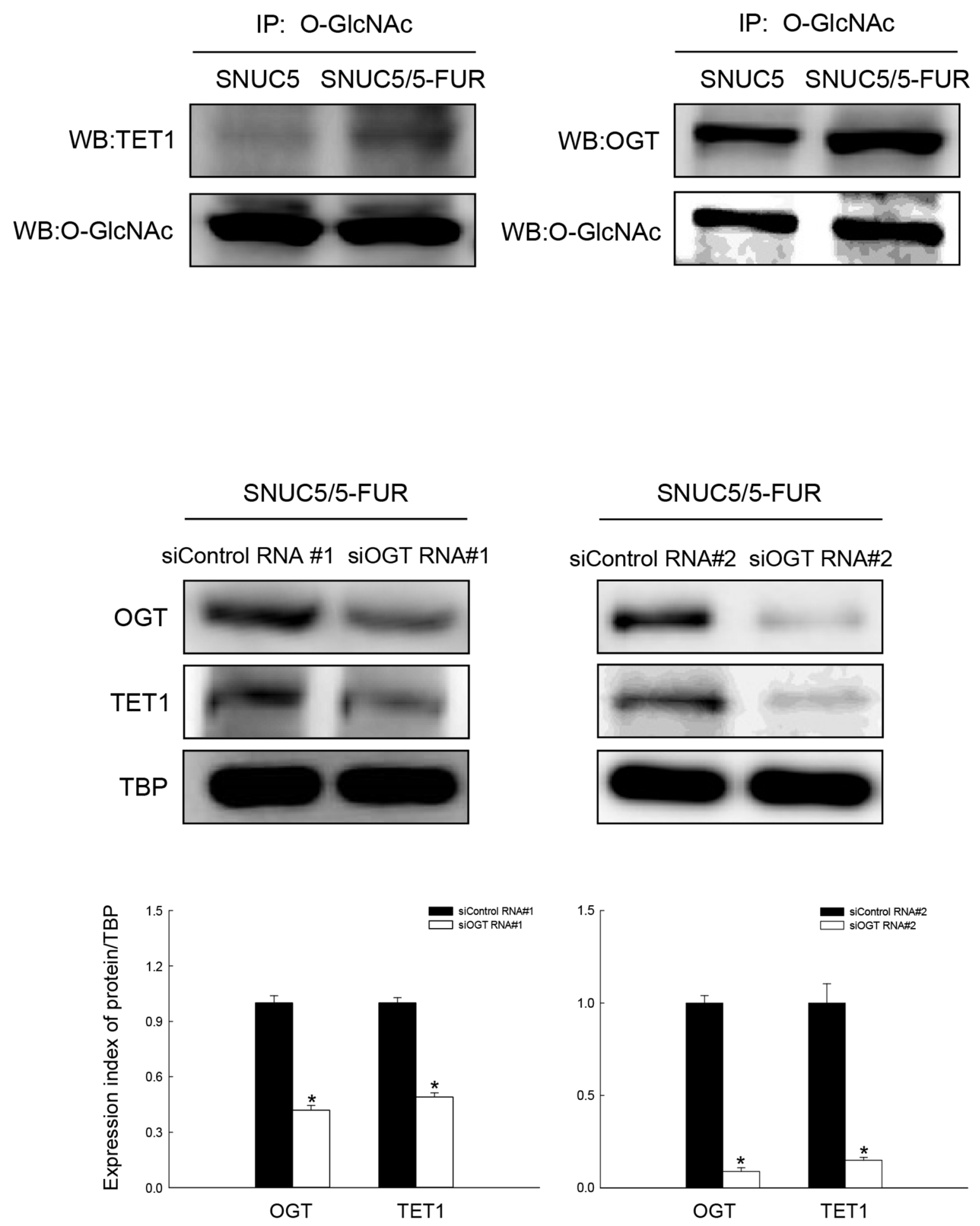

Figure 5 (Continued ): C. The O-GlcNAcylated TET1 or O-GlcNAcylated OGT was examined by immunoprecipitation analyses using anti-O-GlcNAc antibody followed by Western blotting with anti-TET1 and anti-OGT antibodies. The cells were transfected with nontargeting siRNA (siControl) or siOGT RNA or siTET1 RNA for $24 \mathrm{~h}$. D. Expression pattern of OGT and TET1 in SNUC5/5-FUR cells was determined by Western blot analysis. *Significantly different from siControl-transfected cells $(\mathrm{p}<0.05)$.

(Continued) 

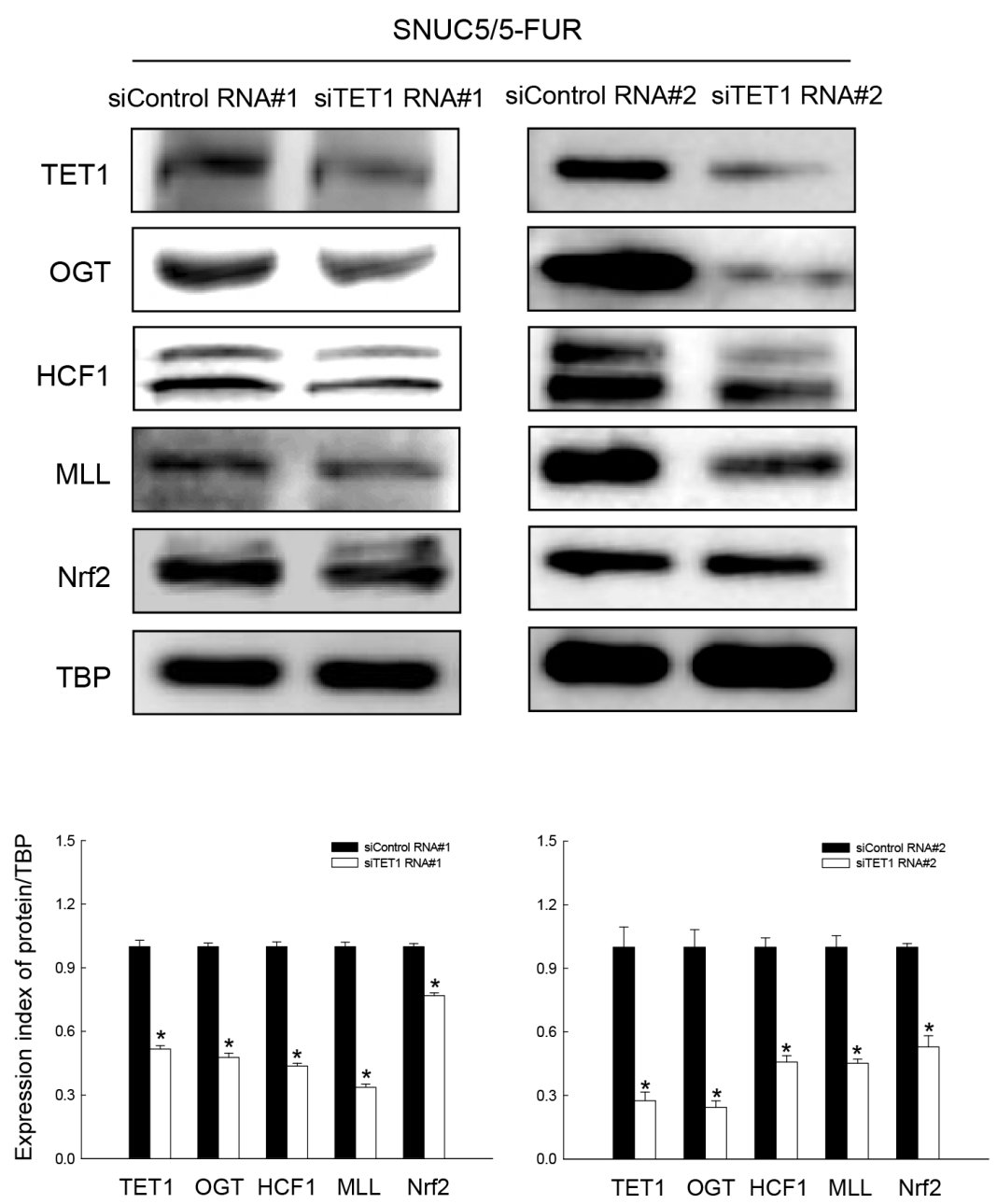

Figure 5 (Continued): E. Expression pattern of TET1, OGT, HCF1, MLL, and Nrf2 in SNUC5/5-FUR cells was determined by Western blot analysis. *Significantly different from siControl-transfected cells $(\mathrm{p}<0.05)$.

binding to the Nrf2 promoter was significantly increased in SNUC5/5-FUR cells, while H3K4Me3 binding to the $\beta$-actin promoter, unrelated to 5 -FU resistance, was unchanged.

\section{5-FU affects histone methyltransferase through reactive oxygen species $(\mathrm{ROS})$ production}

Persistent oxidative stress induces genomic instability, carcinogenesis, and anticancer drug resistance [18]. Recently, we showed that SNUC5/5-FUR cells undergo oxidative stress due to 5-FU-induced intracellular ROS, resulting in activation of TET-dependent DNA demethylation and induction of Nrf2 expression [13]. Therefore, we investigated the effect of 5-FU-induced ROS on H3K4Me3-related proteins. SNUC5/5-FUR cells showed higher intracellular ROS levels than SNUC5 cells detected by using flow cytometry and confocal microscopy after staining of DHR123 (Figure 7A and 7B), and increased Nrf2 mRNA (Figure 7C) and nuclear Nrf2 protein (Figure 7D). SNUC5/5-FUR cells exhibited higher TET1, OGT, HCF1, and MLL than SNUC5 cells (Figure $7 \mathrm{E})$. Treatment with the antioxidant $\mathrm{N}$-acetylcystein (NAC) reduced ROS and expression of Nfr2, TET1, OGT, HCF1, and MLL protein (Figures 7A-7E). These results suggest that SNUC5/5-FUR cells are exposed to oxidative stress condition.

We investigated whether 5-FU induces specific ROS by detecting their intracellular levels. 5-FU treatment of SNUC5 cells increased ROS levels (Figure 7F and 7G), Nrf2 mRNA (Figure 7H), and nuclear Nrf2 protein level (Figure 7I). 5-FU treatment also increased TET1, OGT, HCF1, and MLL protein (Figure 7J). NAC treatment reduced all of these effects (Figures 7F-7J). To identify the nature of 5-FU-mediated ROS, intracellular $\mathrm{H}_{2} \mathrm{O}_{2}, \mathrm{O}_{2}$ , and HO- levels were measured, using DCF-DA, DHE and HPF assays, respectively. The $\mathrm{H}_{2} \mathrm{O}_{2}$ level by DCFDA assay was significantly higher in SNUC5/5-FUR cells 
A

IP: TET1

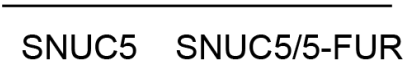

WB:MLL

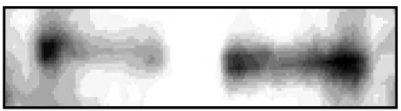

WB:TET1

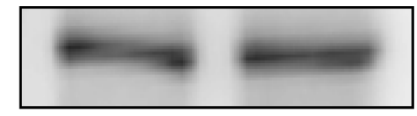

IP: MLL

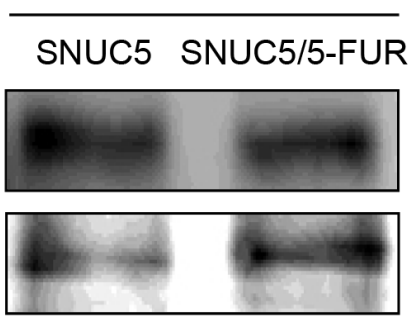

IP: $\lg G$

SNUC5 SNUC5/5-FUR
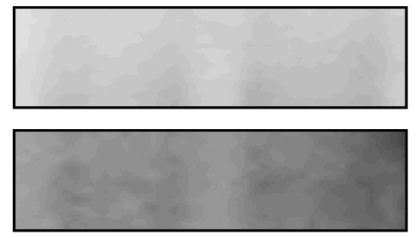

B

TET1-MLL interaction (PLA)
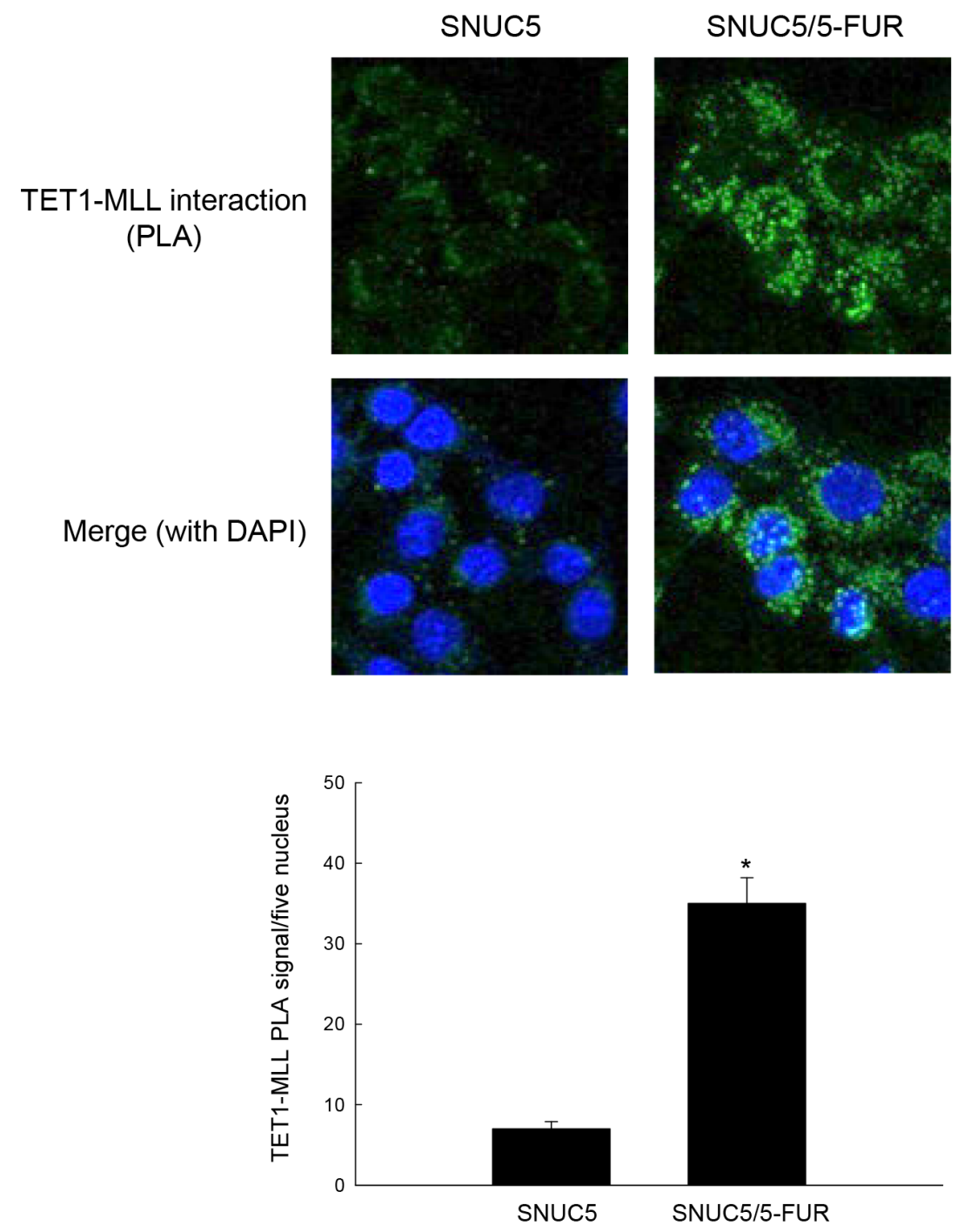

Figure 6: Interaction of TET1 and MLL and binding of H3K4Me3 to Nrf2 promoter in SNUC5/5-FUR cells. A. Interaction between TET1 and MLL was examined by immunoprecipitation analysis using anti-TET1 and anti-MLL antibodies followed by Western blotting with anti-MLL and anti-TET1 antibodies. B. Interaction between TET1 and MLL was assessed by using PLA. Each green spot represents for a single interaction (TET1 and MLL) and DNA was stained with DAPI. *Significantly different from SNUC5 cells ( $<0.05)$.

(Continued) 


\section{C}
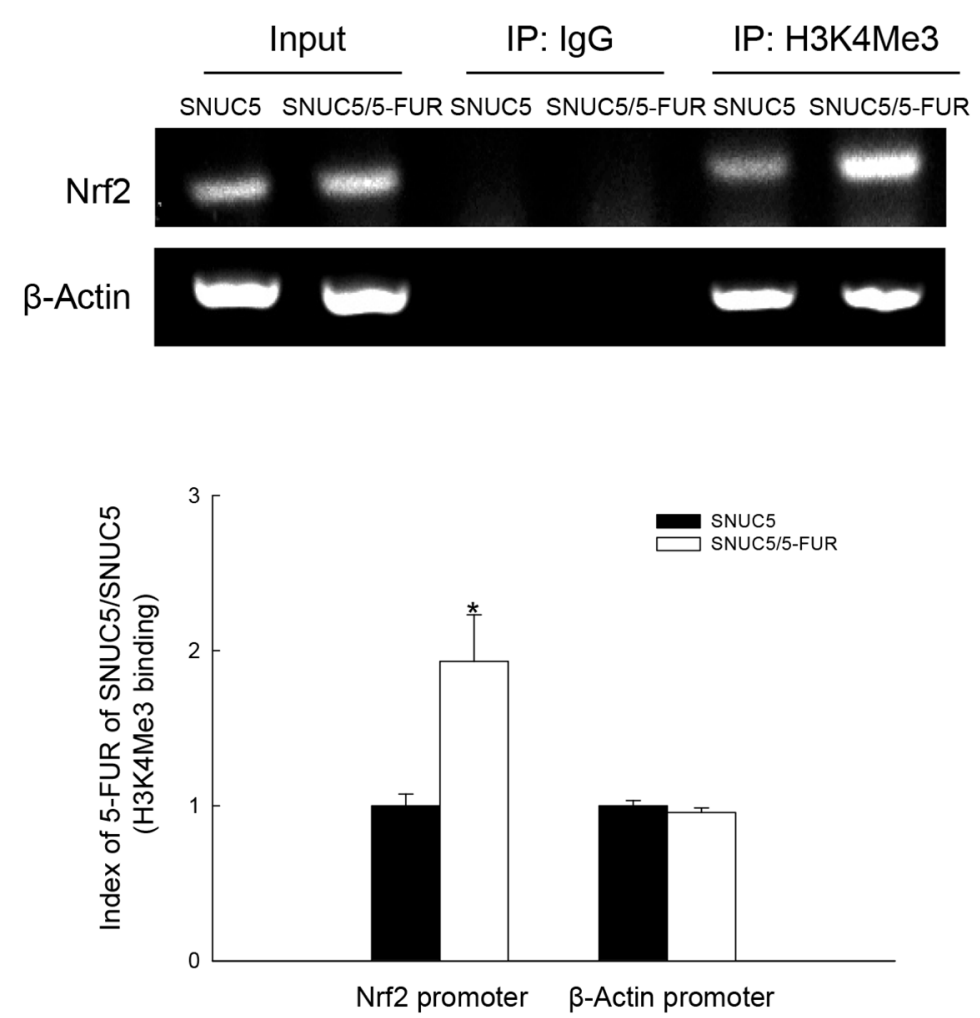

Figure 6 (Continued): C. ChIP analysis was performed using anti-H3K4Me3 antibody and primers to amplify the Nrf2 or $\beta$-actin promoter region. Bands indicate level of $\mathrm{H} 3 \mathrm{~K} 4 \mathrm{Me} 3$ in the $\mathrm{Nrf} 2$ or $\beta$-actin promoter region. Input represents amplification of total DNA from whole cell lysates. * Significantly different from SNUC5 cells $(\mathrm{p}<0.05)$.

than in SNUC5 cells; however, catalase (CAT, a specific scavenger of $\mathrm{H}_{2} \mathrm{O}_{2}$ ) treatment decreased the $\mathrm{H}_{2} \mathrm{O}_{2}$ level in SNUC5/5-FUR cells (Figure 8A). Additionally, SNUC5/5FUR cells exhibited increased $\mathrm{O}_{2}^{-}$level, detected by a DHE fluorescence dye, compared to SNUC5 cells; the presence of superoxide dismutase (SOD, a specific scavenger of $\mathrm{O}_{2}^{-}$) significantly reduced the $\mathrm{O}_{2}^{-}$level in SNUC5/5-FUR cells (Figure 8B). Next, we assessed intracellular HOradical generation in SNUC5 and SNUC5/5-FUR cells. HPF fluorescence intensity (FI) was significantly higher in SNUC5/5-FUR cells compared to SNUC5 cells. Addition of dimethyl sulfoxide (DMSO), an HO- radical scavenger, significantly decreased HO- (Figure 8C). These results suggest that 5-FU induces various ROS radicals including $\mathrm{H}_{2} \mathrm{O}_{2}, \mathrm{O}_{2}^{-}$, and $\mathrm{HO} \cdot$ and the effect of 5-FU on histone methylation is mediated by its induction of these ROS.

\section{DISCUSSION}

Recently, we demonstrated that TET1-mediated Nrf2 expression mediates 5-FU resistance in Colon cancer cells [13]. In the present study, we showed that expression of Nrf2 is upregulated via MLL-mediated histone modification and DNA demethylation.
Di- or trimethylation of histone $\mathrm{H} 3$ at lysine 4 (H3K4) is found at actively transcribed genes [19] and is mediated by the MLL/COMPASS-like complexes [20, 21]. MLL/COMPASS-like complexes contain several wellcharacterized, common subunits; HCF1, ASH2, WDR5 and $\mathrm{RbBP} 5$, which are conserved between yeast and humans [22-24]. These subunits are thought to constitute a common MLL/COMPASS-like complex that forms a platform that mediates the MLL enzyme interaction with H3K4 substrate [22, 24-26]. H3K4 methylation has been associated with a removal of repressive H3K9 methylation or H3K27 methylation by MLL/COMPASSassociated histone demethylases [27-29]. Observations that the deposition of activating methylation events on H3K 4 correlates with the removal of silencing methylation events on H3K27 have important implications for the regulation of bivalent genes, including cytokine-inducible genes of the immune system.

Our data show that HCF1, an integral component of the MLL/COMPASS-like complex, is highly expressed in SNUC5/5-FUR cells compared to SNUC5 cells and exists in stable complex with MLL. In addition, HCF1 interacts with and is modified by OGT [30], which adds O-GlcNAc to serine and threonine residues [31]. HCF1 
A
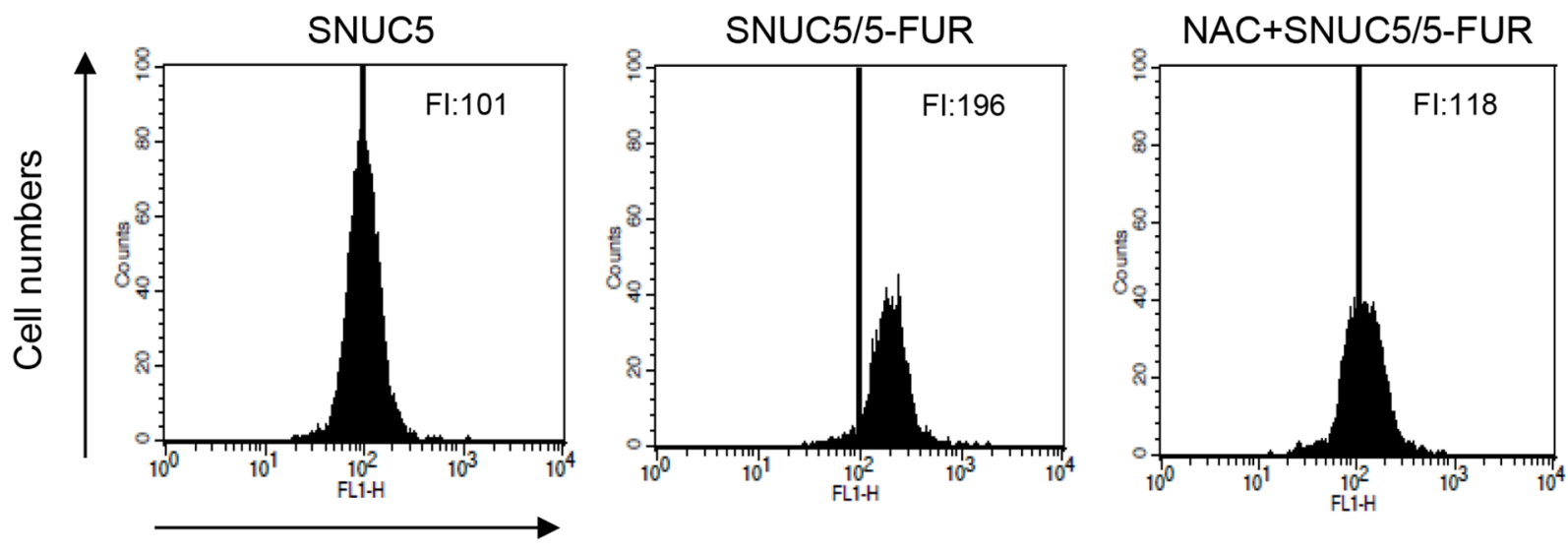

Fluorescence intensity

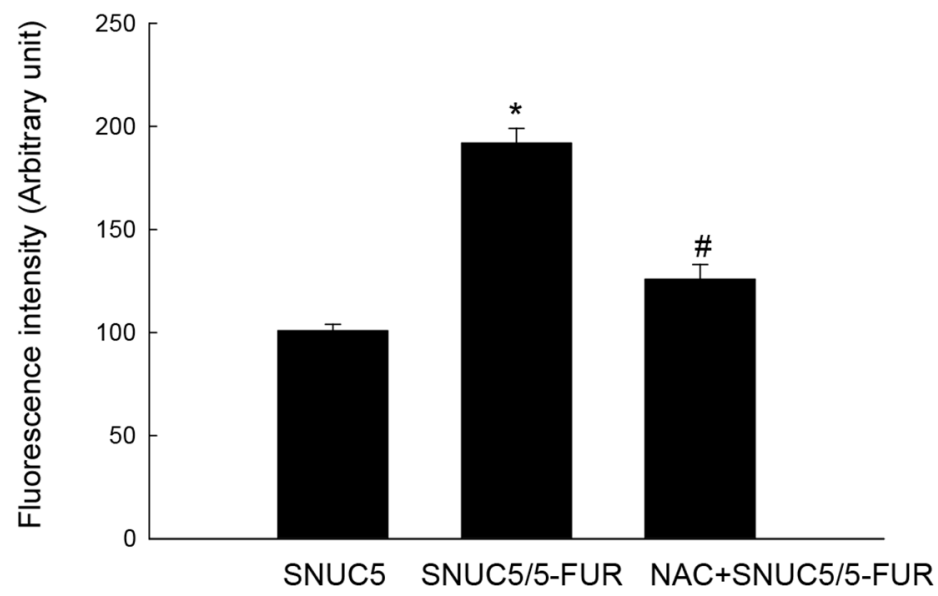

B

SNUC5

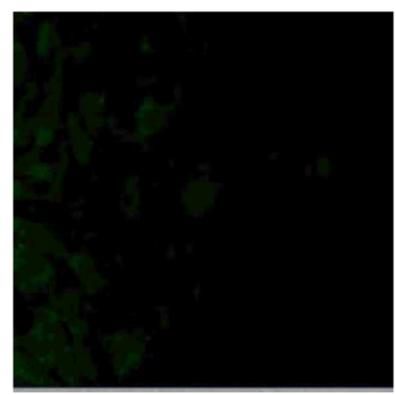

SNUC5/5-FUR

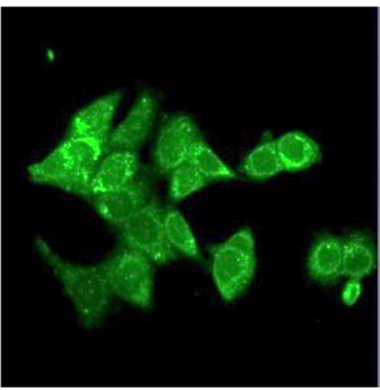

NAC+SNUC5/5-FUR

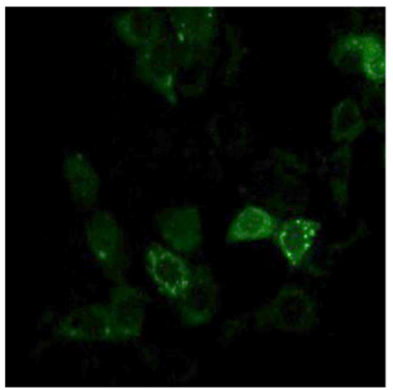

Figure 7: 5-FU-produced ROS involved in histone methyltransferase-mediated Nrf2 expression. SNUC5/5-FUR cells were pre-treated with $500 \mu \mathrm{M} \mathrm{NAC}$, plated, and incubated for $48 \mathrm{~h}$. Then, cells were treated with $10 \mu \mathrm{M}$ DHR123 and incubated for 30 $\min$ at $37^{\circ} \mathrm{C}$. The intracellular ROS were detected by A. flow cytometry and B. confocal imaging. FI indicates the fluorescence intensity of DHR-123. *Significantly different from SNUC5 cells $(\mathrm{p}<0.05)$, and ${ }^{\#}$ significantly different from SNUC5/5-FUR cells $(\mathrm{p}<0.05)$.

(Continued) 
C
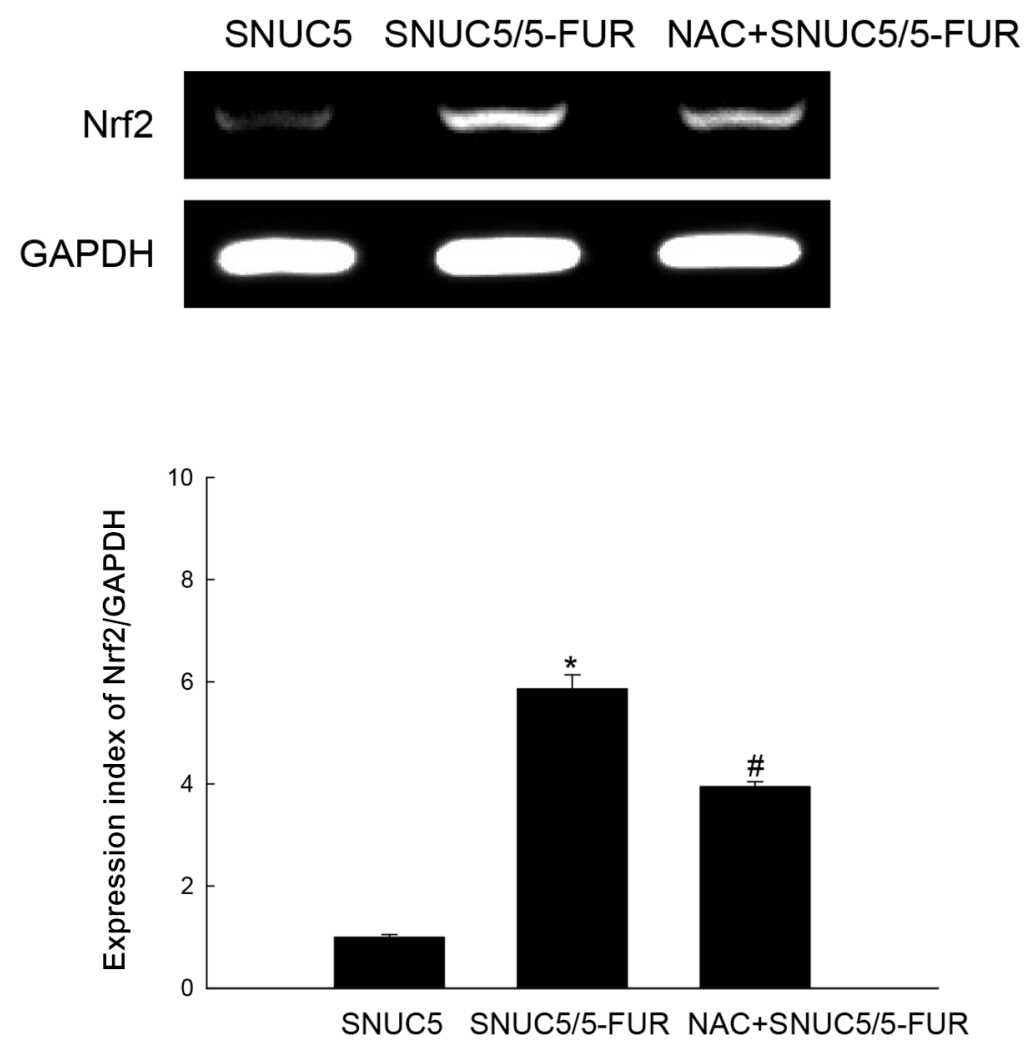

D

SNUC5 SNUC5/5-FUR NAC+SNUC5/5-FUR

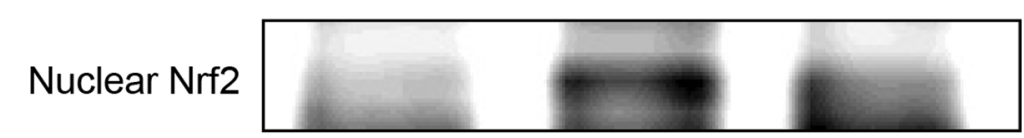

TBP

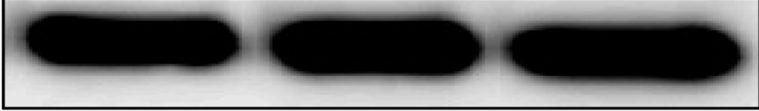

Cytosolic Nrf2

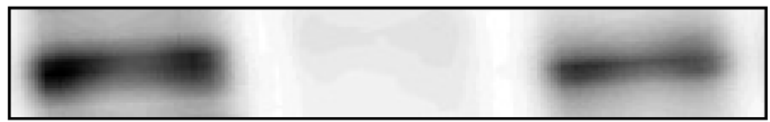

Actin

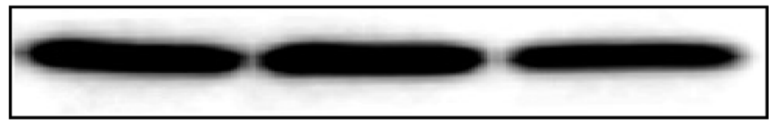

Figure 7 (Continued): C. Expression pattern of Nrf2 mRNA was determined by RT-PCR analysis. * Significantly different from SNUC5 cells $(\mathrm{p}<0.05)$, and "significantly different from SNUC5/5-FUR cells $(\mathrm{p}<0.05)$. D. Expression pattern of nuclear and cytosolic Nrf2 protein was determined by Western analysis. 

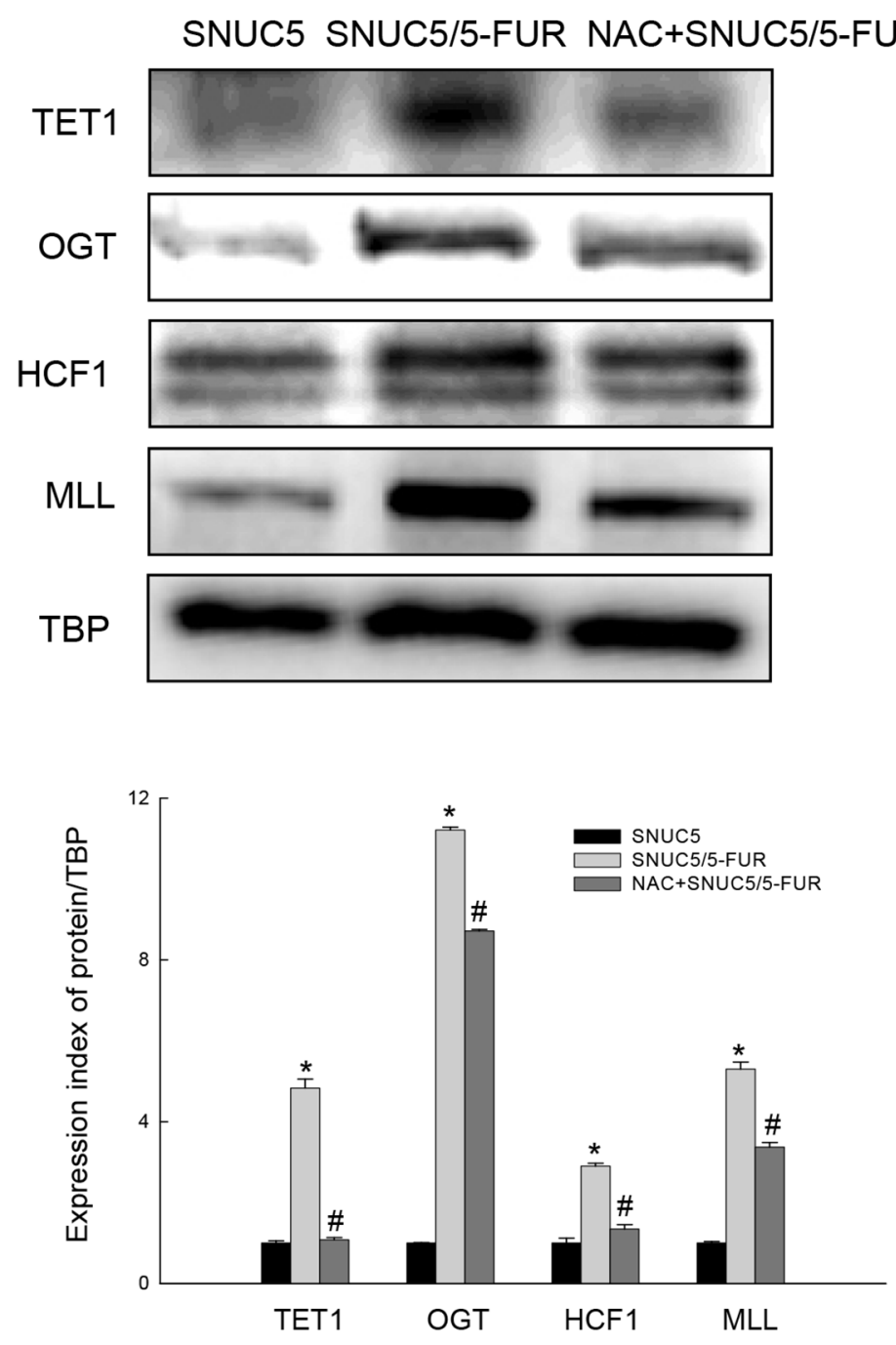

Figure 7 (Continued): E. Expression patterns of TET1, OGT, HCF1, and MLL in NAC pre-treated SNUC5/5-FUR cells determined by Western blot analysis. *Significantly different from SNUC5 cells $(\mathrm{p}<0.05)$, and ${ }^{*}$ significantly different from SNUC5/5-FUR cells $(\mathrm{p}<0.05)$. Also, SNUC5 cells were pre-treated with $500 \mu \mathrm{M}$ of NAC and incubated for an additional $1 \mathrm{~h}$ at $37^{\circ}$. Cells were then treated with $140 \mu \mathrm{M}$ 5-FU for 48 h. $10 \mu \mathrm{M}$ of DHR123 was added to plate and incubated for an additional $30 \mathrm{~min}$ at $37^{\circ} \mathrm{C}$.

(Continued)

undergoes proteolytic maturation process at six centrally located $\mathrm{HCF}-1_{\mathrm{PRO}}$-repeat sequences resulting in stably associated $\mathrm{HCF} 1_{\mathrm{N}}$ and $\mathrm{HCF} 1_{\mathrm{C}}$ subunits. Deplus et al. reported that this GlcNAcylated, stable HCF1 is necessary for the integrity of the SET1/COMPASS complex [4]. Also, our data show that OGT is highly expressed in SNUC5/5-FUR cells compared to SNUC5 cells and exists in complex with HCF1 and MLL. The SET1/COMPASS complex trimethylates lysine 4 of histone $\mathrm{H} 3$ (H3K4Me3). $\mathrm{H} 3 \mathrm{~K} 4 \mathrm{Me} 3$ in the nucleosome promotes transcription of nearby DNA. OGT and TET2/3 co-localize with $\mathrm{CpG}$ islands and transcription start sequences and TET2/3OGT interacts with all components of the SET1/ COMPASS complex [4]. By reducing TET2 and TET3 expression levels through RNA interference, reduced
TET expression leads to decreased OGT activity, reduced HCF1 GlcNAcylation, and, lower levels of H3K4Me3. In other words, less TET $2 / 3$ protein resulted in less HCF 1 GlcNAcylation, fewer SET1/COMPASS complexes, less $\mathrm{H} 3 \mathrm{~K} 4 \mathrm{Me} 3$, and lower transcriptional activity [4]. We show that TET1 interacts with OGT and undergoes O-GlcNAcylation, and TET1-mediated Nrf2 expression is dependent on OGT. OGT posttranslationally modifies protein substrates by adding GlcNAcyl moieties to serine/ threonine residues [32]. O-GlcNAcylation is crucial to diverse biological processes including nutrient and growth factor sensing, cell cycle progression, and stress response $[6,33]$. Vella et al. demonstrated that OGT preferentially associates with TET1 at gene promoters in close proximity to $\mathrm{CpG}$-rich transcription start sites and OGT-mediated 
SNUC5
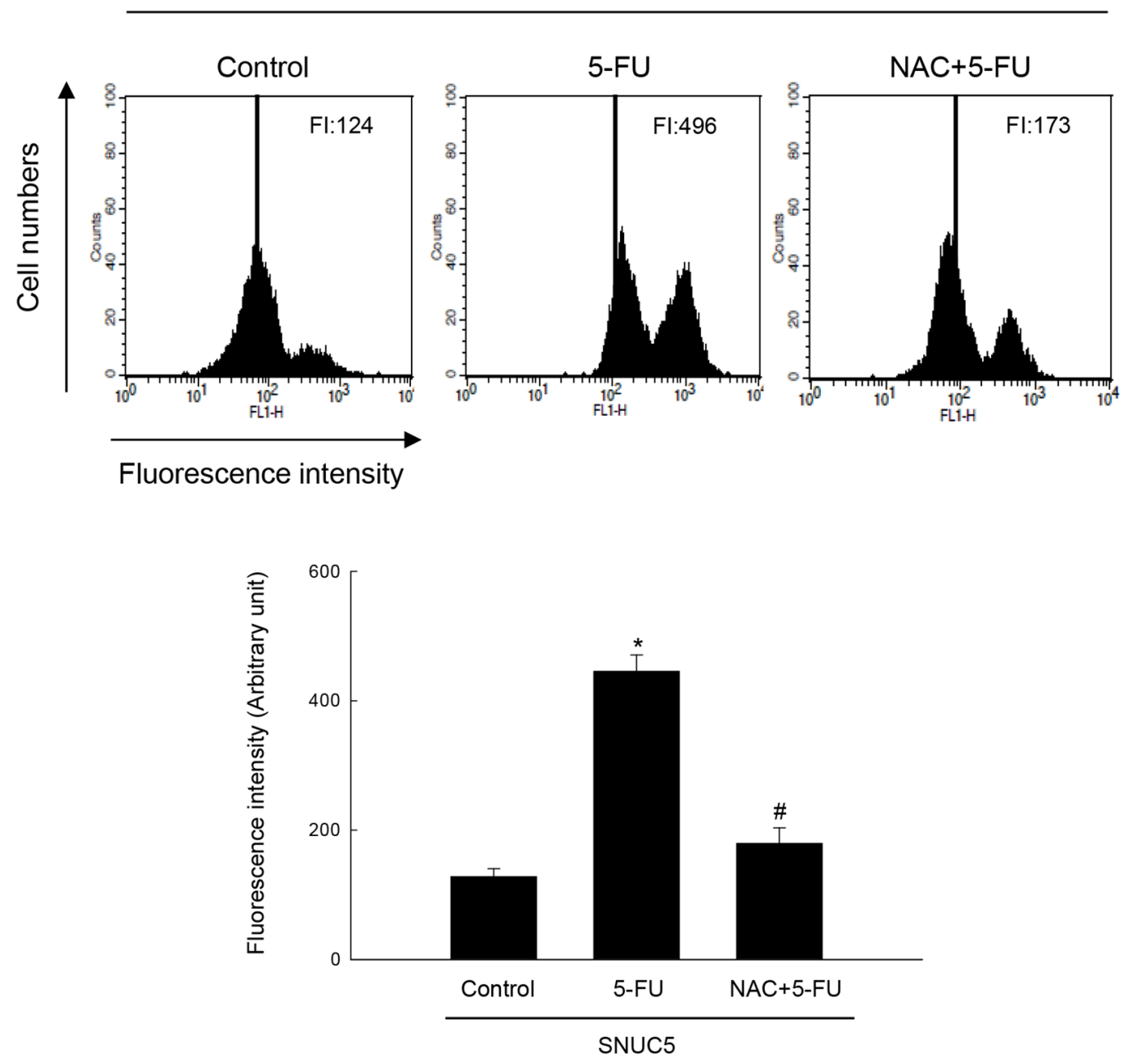

G

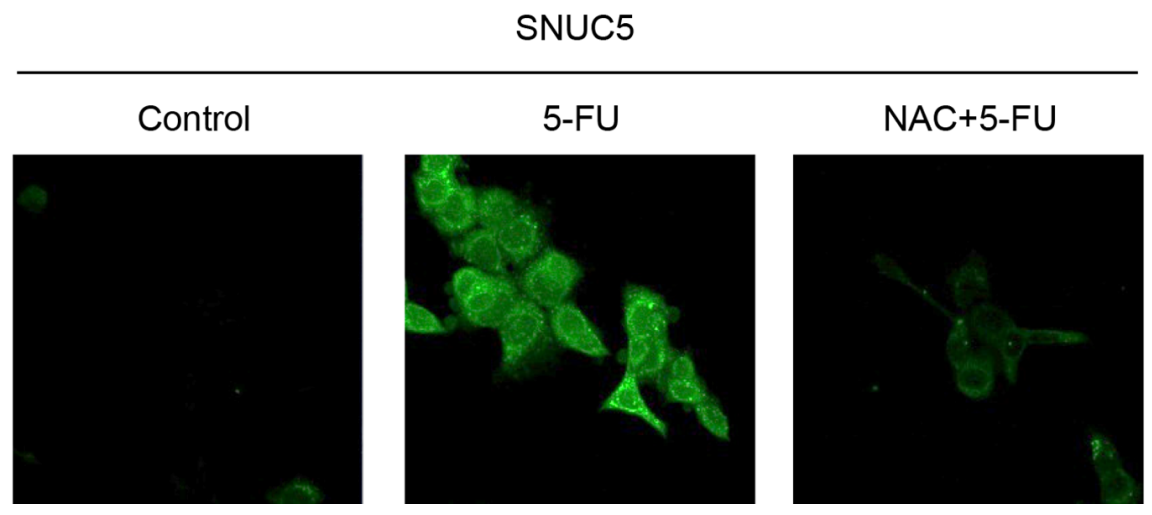

Figure 7 (Continued): F. The intracellular ROS level was detected by flow cytometry and G. confocal imaging. FI indicates the fluorescence intensity of DHR123. *Significantly different from SNUC5 cells $(\mathrm{p}<0.05)$, and "significantly different from 5-FU-treated SNUC5 cells $(\mathrm{p}<0.05)$.

(Continued) 

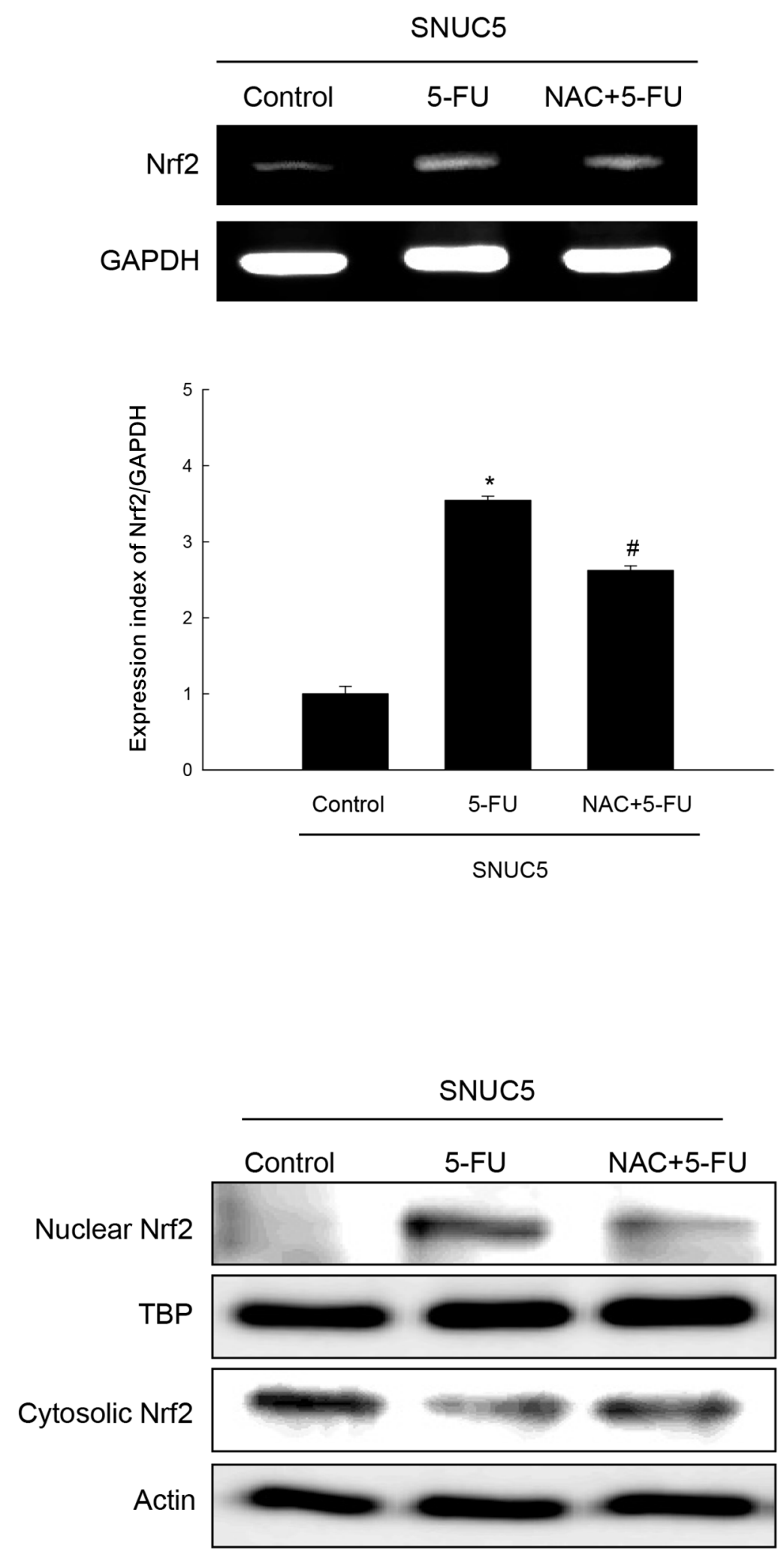

Figure 7 (Continued): H. Expression pattern of Nrf2 mRNA was determined by RT-PCR analysis. *Significantly different from SNUC5 cells $(\mathrm{p}<0.05)$, and "significantly different from 5-FU-treated SNUC5 cells $(\mathrm{p}<0.05)$. I. Expression pattern of nuclear and cytosolic Nrf2 protein was determined by Western analysis.

(Continued) 

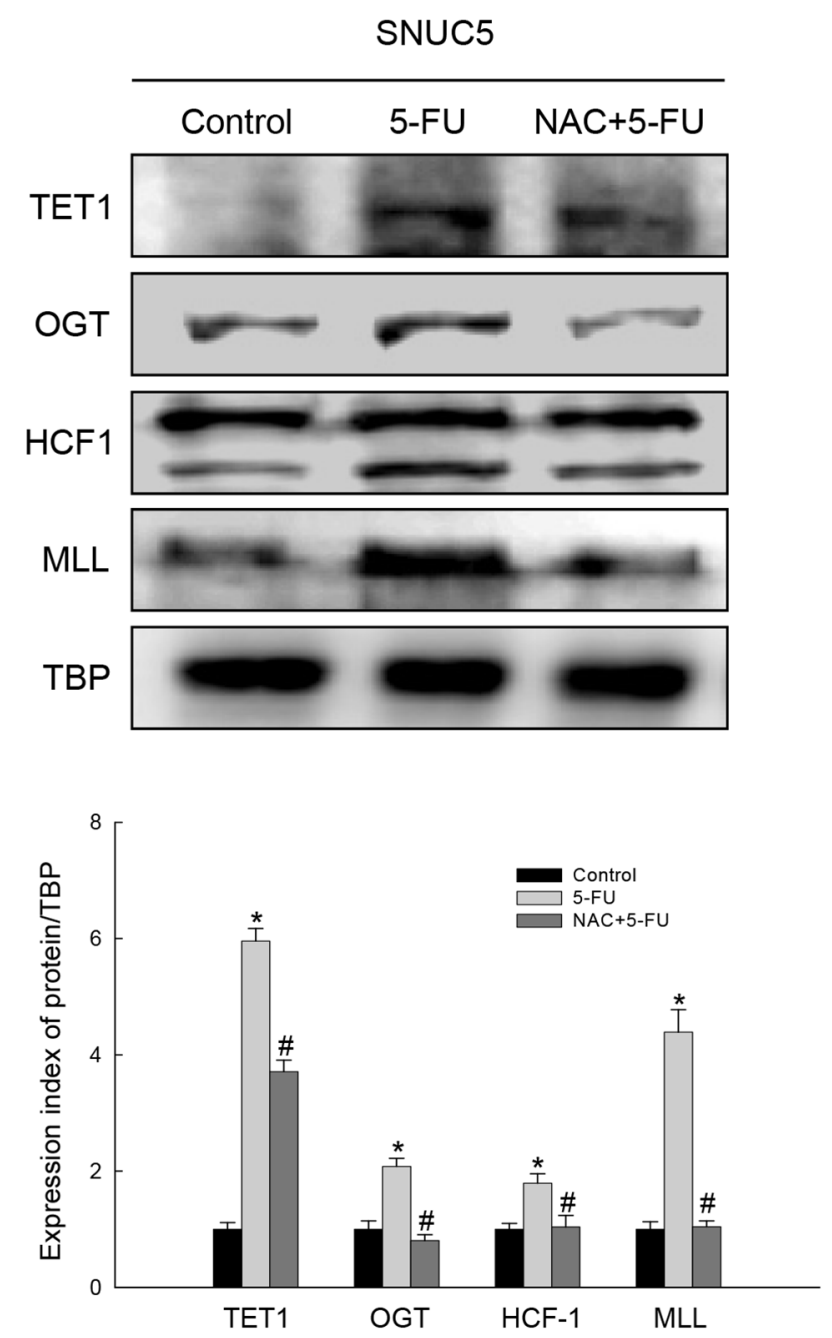

Figure 7 (Continued): J. The expression of TET1 and interaction proteins detected by Western blot analysis. *Significantly different from SNUC5 cells $(\mathrm{p}<0.05)$, and " significantly different from 5-FU-treated SNUC5 cells $(\mathrm{p}<0.05)$.

O-GlcNAcylation stabilizes TET1 activity at promoters [9].

SNUC5/5-FUR cells with higher TET1 and OGT complex showed increased O-GlcNAcylated protein level compared to SNUC5 cells. Deplus et al. demonstrated that TET2 and TET3 regulate GlcNAcylation and H3K4 methylation through OGT and SET1/COMPASS, and TET1 localizes primarily at regions high in H3K4Me3 $[4,10,11]$. This suggests that in addition to reducing DNA methylation, the TET-OGT interaction might recruit proteins required to establish a high $\mathrm{H} 3 \mathrm{~K} 4 \mathrm{Me} 3$ chromatin environment. Depletion of OGT reduces TET1, whereas ectopic expression of wild-type OGT increases TET1 levels. Mutation of the putative O-GlcNAcylation site on TET1 decreases O-GlcNAcylation and the level of the TET1 protein. These results suggest that O-GlcNAcylation increases TET1 protein expression and that TET1- mediated 5-hydroxylmethylcytosine modification is controlled by OGT. Our data confirm that OGT expression is increased in SNUC5/5-FUR cells and that TET1 interacts with OGT. Recent studies also found that OGT interacts with TET family proteins; interestingly, TET proteins appear to recruit OGT to $\mathrm{CpG}$ rich promoters in embryonic stem cells $[4,9,34]$. Knockdown of TET1 or TET2 led to loss of OGT from chromatin [9, 34]; knockdown of TET2 also reduced O-GlcNAc modification of histones [34]. Moreover, interaction with TET2/3 stimulates OGT activity toward HCF1 [4]. Given this connection between OGT, TET proteins, and HCF1, it is likely that TET proteins are key factors in recruiting SET or MLL complexes to CpG islands. In line with this notion, OGT- and TET-binding sites overlap to a large extent with $\mathrm{H} 3 \mathrm{~K} 4 \mathrm{Me} 3$ sites at promoters $[4,9]$. Both OGT activity and its interaction with TET2/3 promoted 
A

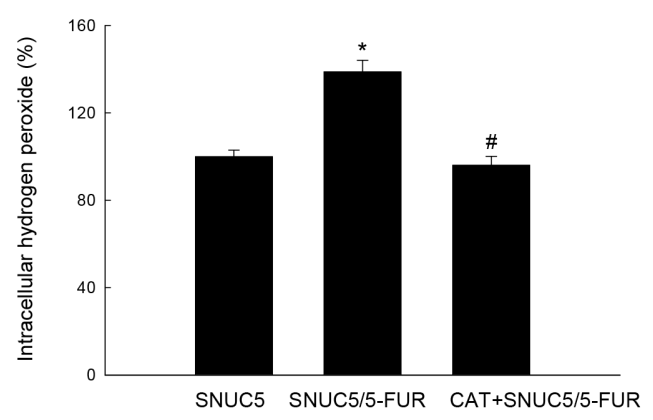

B

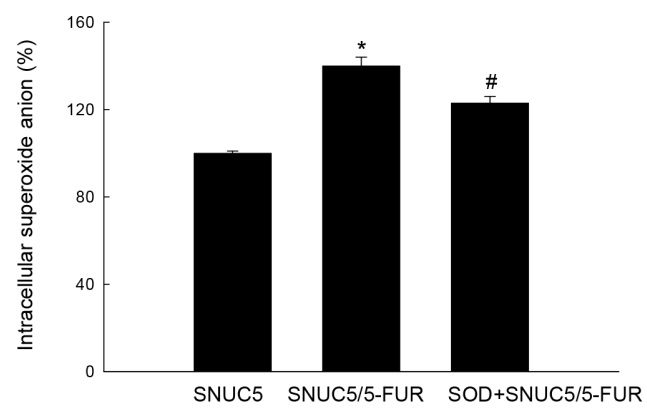

C
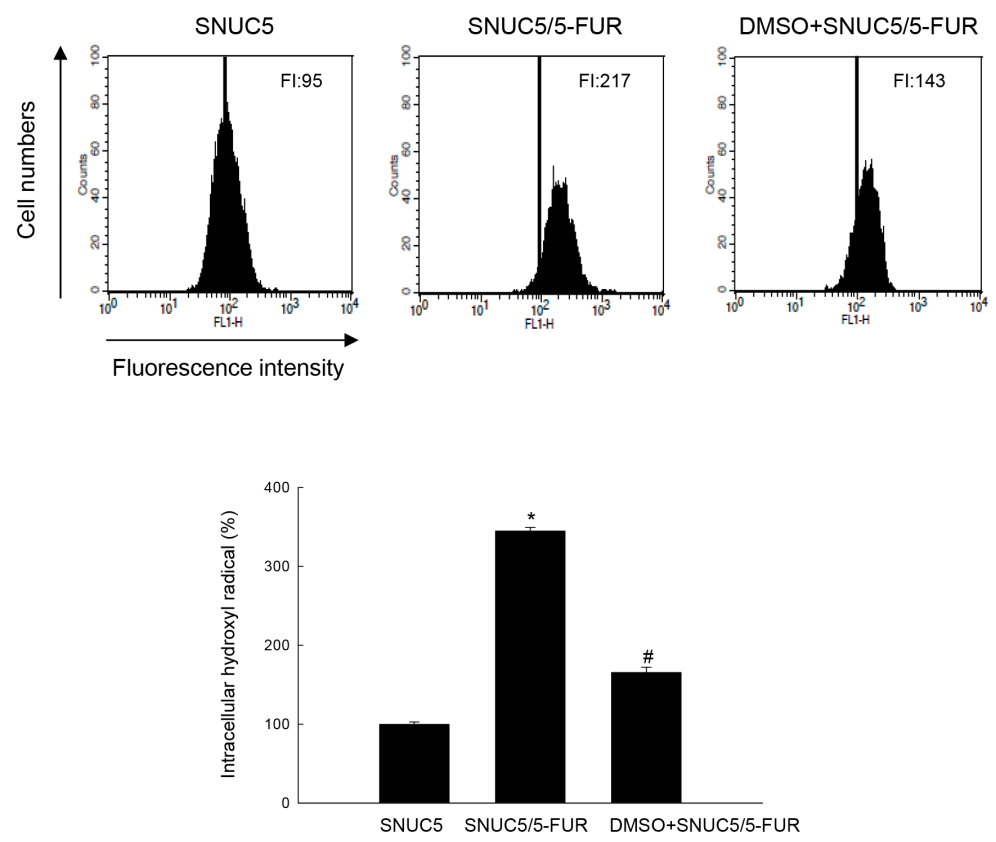

Figure 8: Detection of $\mathrm{H}_{2} \mathrm{O}_{2}, \mathrm{O}_{2}^{-}$, and $\mathrm{HO} \cdot$ in SNUC5 and SNUC5/5-FUR cells. SNUC5/5-FUR cells were pre-treated with specific ROS scavengers, $\mathrm{CAT}$ for $\mathrm{H}_{2} \mathrm{O}_{2}$ at $0.5 \mathrm{U} / \mathrm{ml}$, SOD for $\mathrm{O}_{2}^{-}$at $30 \mathrm{U} / \mathrm{ml}$, and $2 \%$ DMSO for $\mathrm{HO}$ radical, and incubated for $48 \mathrm{~h}$. Then cells were treated with ROS probes ( $25 \mu \mathrm{M}$ of DCF-DA for $\mathrm{H}_{2} \mathrm{O}_{2}, 10 \mu \mathrm{M}$ of DHE for $\mathrm{O}_{2}^{-}$and $10 \mu \mathrm{M}$ of HPF for HO') and incubated for $30 \mathrm{~min}$ at $37^{\circ} \mathrm{C}$. A. The $\mathrm{H}_{2} \mathrm{O}_{2}$ level and $\mathbf{B} \cdot \mathrm{O}_{2}^{-}$level were detected by fluorescence spectroscopy. *Significantly different from SNUC5 cells $(\mathrm{p}<0.05)$, and "significantly different from SNUC5/5-FUR cells $(p<0.05)$. C. HO radical was detected by flow cytometry. FI indicates the fluorescence intensity. *Significantly different from SNUC5 cells $(p<0.05)$, and "significantly different from SNUC5/5-FUR cells $(p<0.05)$. 
chromatin association of SET complexes and H3K4 methylation in HEK293 cells [4]. Moreover, previously, we demonstrated that 5-FU treatment stimulates ROS production and is associated with TET1 activation [13]. Our data show that 5-FU treatment generated various ROS such as $\mathrm{H}_{2} \mathrm{O}_{2}, \mathrm{O}_{2}$-and $\mathrm{HO} \cdot$. In summary, $\mathrm{Nrf} 2$ transcription factor in 5-fluorouracil-resistant colon cancer cells is upregulated via interaction of DNA demethylase and histone methyltransferase through oxidative stress (Figure 9).

\section{MATERIALS AND METHODS}

\section{Cell culture}

SNUC5 colon cancer cells (KCLB no. 0000C5) were obtained from the Korean Cell Line Bank (Seoul, Republic of Korea) and cultured at $37^{\circ} \mathrm{C}$ in a $5 \% \mathrm{CO}_{2}$ atmosphere using RPMI 1640 medium with 10\% heat-inactivated FBS. The chemo-resistant SNUC5 (SNUC5/5-FUR, SNUC5/OXTR) cells were selected from the parental wild type SNUC5 by chronic exposure to 5-FU and OXT (Sigma-Aldrich Co., St. Louis, MO, USA), respectively, in intermittent dosage schedules at sufficient intervals to permit the expression of the resistance phenotypes. The cells were exposed to the drugs starting from $1 \times \mathrm{IC}_{50}(5$ FU $17.5 \mu \mathrm{M}$ and OXT $7.14 \mu \mathrm{M}$ ), and the concentrations were escalated at an increasing rate of $50 \%$, and then finally cultured at fixed concentrations over a level of 10 times the $\mathrm{IC}_{50}$ of 5-FU and OXT, respectively. Cells were cultured in a fixed 5-FU $(140 \mu \mathrm{M})$ and OXT $(7.14 \mu \mathrm{M})$ concentration for all subsequent experiments [35]. Human ovarian cancer cells A2780 and its cisplatin resistant derivative A2780/CR were obtained from Sigma-Aldrich Co and were cultured in RPMI-1640 supplemented with $10 \%$ FBS and $1 \%$ penicillin/streptomycin. To maintain

\section{5-FU}

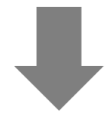

ROS

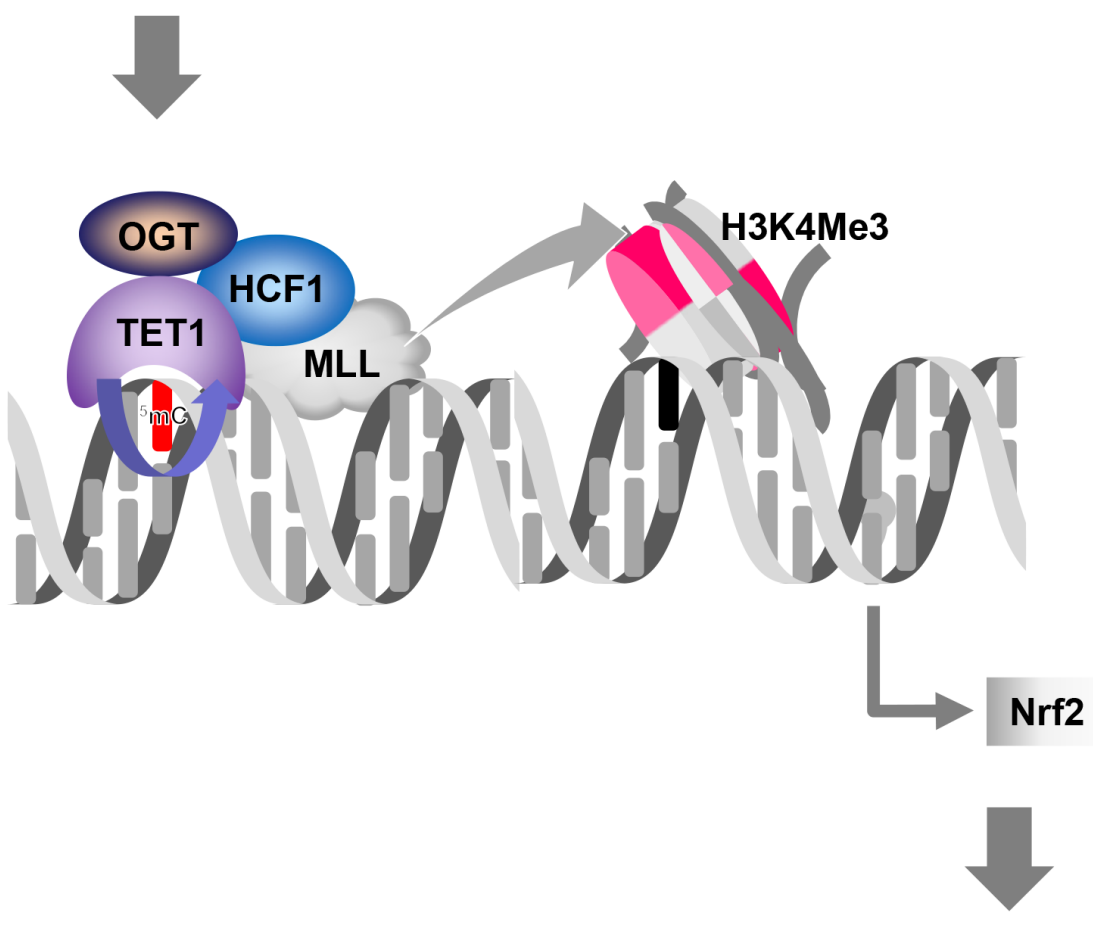

Chemo-resistance

Figure 9: The proposed diagram for DNA and histone modification mechanism of resistance to 5-FU in colon cancers. 5-FU induces oxidative stress via generation of ROS. Then, oxidative stress-activated TET1 protein recruits OGT to the Nrf2 promoter, and OGT GlcNAcylates HCF1, a component of MLL/COMPASS-like complex. This H3K4Me3 methyltransferase complex methylates H3K4, resulting in transcriptional activation of $\mathrm{Nrf} 2$, and leads to chemo-resistance. 
Table 1: Information on siRNAs $\left(5^{\prime} \rightarrow 3^{\prime}\right)$ used

\author{
SiMLL RNA\#1 \\ siMLL RNA \#2 \\ siHAT1 RNA\#1 \\ siHAT1 RNA \#2 \\ siHCF1 RNA\#1 \\ siHCF1 RNA\#2 \\ siOGT RNA\#1 \\ siOGT RNA \#2 \\ siTET1 RNA\#1 \\ siTET1 RNA\#2 \\ siControl RNA \#1 \\ siControl RNA \#2
}

sc-38039

Sense : GUCACAGUAGGUGAUCCUU

Antisense : AAGGAUCACCUACUGUGAC

sc-37948

Sense : GAAAGAUGGCACUACUUUC

Antisense : GAAAGUAGUGCCAUCUUUC

sc-37996

Sense : CCGUCCCUGACUAUAACCA

Antisense : UGGUUAUAGUCAGGGACGG

sc-40780

Sense : GAUUAACCGAGGACAGAUU

Antisense : AAUCUGUCCUCGGUUAAUC

sc-90457

Sense : CAGUGUAACCAGCACAGUU

Antisense : AACUGUGCUGGUUACACUG

sc-37007

Sense : UUCUCCGAACGUGUCACGUTT

Antisense : ACGUGACACGUUCGGAGAATT

resistance, A2780/CR cells were treated with $1 \mu \mathrm{M}$ cisplatin after every third passage.

\section{Western blot analysis}

Cells were harvested and lysed on ice in $1 \mathrm{ml}$ of lysis buffer (10 mM Tris-HCl, pH 7.9, $10 \mathrm{mM} \mathrm{NaCl,} 3 \mathrm{mM}$ $\mathrm{MgCl}_{2}$, and $1 \% \mathrm{NP}-40$ ) for $4 \mathrm{~min}$. After centrifugation for $10 \mathrm{~min}$ at $3,000 \times \mathrm{g}$, the pellets were re-suspended in $50 \mu \mathrm{l}$ of extraction buffer (20 mM HEPES, pH 7.9, 20\% glycerol, $1.5 \mathrm{mM} \mathrm{MgCl}_{2}, 0.2 \mathrm{mM}$ EDTA, $1 \mathrm{mM}$ DTT, and $1 \mathrm{mM}$ PMSF), incubated on ice for $30 \mathrm{~min}$, and centrifuged at $13,000 \times \mathrm{g}$ for $5 \mathrm{~min}$. Following measurement of the protein concentration, supernatants were stored at $-70^{\circ} \mathrm{C}$. Aliquots of the lysates (40 $\mu \mathrm{g}$ of protein) were boiled for $5 \mathrm{~min}$ and electrophoresed on a 10\% SDS-polyacrylamide gel. Proteins were transferred onto nitrocellulose membranes, which were subsequently incubated with primary antibodies, followed by secondary immunoglobulin-Ghorseradish peroxidase conjugates (Pierce, Rockford, IL, USA). The primary antibodies were as follows: TET1 (Abcam, Cambridge, MA, USA; ab191698), HDAC1 (Santa Cruz Biotechnology, Santa Cruz, CA, USA; sc7872), HAT1 (Santa Cruz Biotechnology; sc-366092), H3K9Ac (Cell Signaling Technology, Danvers, MA, USA; \#9671), MLL (Active Motif, Carlsbad, CA, USA; \#61295), H3K4Me3 (Abcam; ab8580), G9a (Santa Cruz Biotechnology; sc-22877), H3K9Me2 (Abcam; ab1220), HO-1 (Cell Signaling Technology; \#5853), HCF1 (Novus Biologicals, Littleton, CO, USA; NB-68209),
Nrf2 (Santa Cruz Biotechnology; sc-722); OGT (Santa Cruz Biotechnology; sc-32921), O-GlcNAc (Santa Cruz Biotechnology; sc-59623); TBP (Abcam; ab818) and actin (Santa Cruz Biotechnology;sc-1616). Protein bands weredetected using an enhanced chemiluminescence Western blotting detection kit (Amersham, Little Chalfont, UK). The protein bands were visualized using a luminescent image analyzer and quantified.

\section{Transient transfection of small interfering RNAs (siRNAs)}

Cells were seeded at a density of $1.5 \times 10^{5}$ cells/ $\mathrm{ml}$ in 24 well plates and allowed to reach approximately $50 \%$ confluence on the day of transfection. Cells were transfected with $10-50 \mathrm{nM}$ of a mismatched siRNA control (siControl) or siRNAs against MLL, HAT1, TET1, HCF1, or OGT (Table 1) using Lipofectamine RNAiMax (Invitrogen, Carlsbad, CA, USA) according to the manufacturer's instructions. At $24 \mathrm{~h}$ after transfection, the cells were examined by Western blotting.

\section{Immunoprecipitation method}

Cells were lysed in 0.5\% NP40, $10 \mathrm{mM}$, Tris- $\mathrm{HCl}$ (pH 8.0), $150 \mathrm{mM} \mathrm{NaCl}$, and $5 \mathrm{mM} \mathrm{MgCl}_{2}$. Lysates were incubated overnight at $4^{\circ} \mathrm{C}$ with $\mathrm{HCF} 1, \mathrm{MLL}$, TET1, OGT, or IgG antibody. Immune complexes were collected with protein A/G PLUS-beads (Santa Cruz Biotechnology) overnight at $4^{\circ} \mathrm{C}$, and washed with immunoprecipitation 
buffer. Equal amounts of the precipitates were separated by SDS-polyacrylamide gel electrophoresis, followed by Western blot analysis with antibodies specific for HCF1, MLL, TET1, and OGT.

\section{Proximity ligation assay (PLA)}

The mouse/rabbit red starter Duolink kit (SigmaAldrich Co.) was used for this experiment. The cells were seeded at $1.5 \times 10^{3}$ cells $/ \mathrm{ml}$ in a 4 well chamber slide (Thermo Fisher, Scoresby, Victoria, Australia). After washing with PBSCM (PBS, $1 \mathrm{mM} \mathrm{CaCl}_{2}, 1 \mathrm{mM}$ $\mathrm{MgCl}_{2}$ ) three times, the cells were fixed with cold $3 \%$ paraformaldehyde (PFA) for $15 \mathrm{~min}$ at room temperature (RT). The fixed cells were then washed with $50 \mathrm{mM}$ $\mathrm{NH}_{4} \mathrm{Cl}$ to quench the PFA followed by a PBSCM wash and permeabilized with $0.1 \%$ saponin in PBSCM for 15 min at RT. After permeabilization the cells were incubated in the blocking buffer (provided with the kit) overnight at $37^{\circ} \mathrm{C}$ in a humidified chamber and then incubated with primary antibodies: rabbit anti-TET1 (1:500), goat anti-TET1 (1:100), mouse anti-OGT (1:500), rabbit antiMLL (1:1000) or goat anti-HCF-1 (1:100) diluted in fluorescence dilution buffer (FDB) (5\% fetal calf serum, $5 \%$ normal donkey serum, $2 \%$ bovine serum albumin in PBSCM, pH7.6) for $2 \mathrm{~h}$ at RT. For the rest of the protocol the manufacturer's instructions were followed. Briefly, the cells were washed in buffer A (supplied with the kit) 3 times for $15 \mathrm{~min}$ and incubated with the PLA probes for $1 \mathrm{~h}$ at $37^{\circ} \mathrm{C}$ in a humid chamber. This was followed by a $10 \mathrm{~min}$ wash and a $5 \mathrm{~min}$ wash in buffer $\mathrm{A}$. The ligation reaction was carried out at $37^{\circ} \mathrm{C}$ for $1 \mathrm{~h}$ in a humid chamber followed by a $10 \mathrm{~min}$ wash and $5 \mathrm{~min}$ wash in buffer A. The cells were then incubated with the amplification mix for $2 \mathrm{~h}$ at $37^{\circ} \mathrm{C}$ in a darkened humidified chamber. After washing with $1 \times$ buffer B (supplied with the kit) for $10 \mathrm{~min}$ followed by $1 \mathrm{~min}$ wash with $0.01 \times$ buffer B the cells were mounted using the mounting media supplied with the kit.

\section{Reverse transcription-polymerase chain reaction (RT-PCR)}

Total RNA was isolated using Trizol (GibcoBRL, Grand Island, NY, USA). PCR conditions for Nrf2, MLL, and housekeeping gene, GAPDH, were: 35 cycles of $94^{\circ} \mathrm{C}$ for $45 \mathrm{sec} ; 53^{\circ} \mathrm{C}$ for $45 \mathrm{sec}$; and $72^{\circ} \mathrm{C}$ for 60 sec. The primer pairs (Bioneer, Daejeon, Republic of Korea) were as follows (forward and reverse, respectively): Nrf2, 5'-GGCCCGGACTCTTGC-3' and 5'-GGCGGCCCTGTTCC-3'; MLL，5'-GACAAAGGG AATGGCAAGAA-3' and 5'-TATCCTGCTGCTCAGC CTCT-3' and GAPDH, 5'-AAGGTCGGAGTCAAC GGATTT-3', and 5'-GCAGTGAGGGTCTCTCTCCT-3'. Amplified products were resolved by $1 \%$ agarose gel electrophoresis, stained with ethidium bromide, and photographed under ultraviolet light.

\section{Chromatin immune-precipitation (ChIP) assay}

The ChIP assay was performed using the Simple ChIPTM enzymatic chromatin IP kit (Cell Signaling Technology) according to the manufacturer's protocol with slight modifications. Briefly, cells were cross-linked by addition of $1 \%$ formaldehyde. Chromatin was prepared and digested with nuclease for $12 \mathrm{~min}$ at $37^{\circ} \mathrm{C}$. ChIP was performed with an antibody against tri-methylated histone H3 lysine 4 (H3K4Me3) and mouse IgG. Antibodies were added to the chromatin digests and incubated with constant rotation overnight at $4^{\circ} \mathrm{C}$. ChIP-grade protein $\mathrm{G}$ magnetic beads were then added to capture the immune complexes. The beads were washed and the immune-precipitates were eluted with ChIP elution buffer. The cross-links were reversed by incubation at $65^{\circ} \mathrm{C}$ for $30 \mathrm{~min}$. Proteinase $\mathrm{K}$ was added and samples were incubated at $65^{\circ} \mathrm{C}$ for $2 \mathrm{~h}$. The immunoprecipitated DNA fragments were purified using spin columns. DNA that was recovered from the immunoprecipitated complex was subjected to 35 cycles of PCR. PCR of the Nrf2 promoter region across the H3K4Me3 binding sites within -505 to -254 of the Nrf2 promoter was performed: sense, 5'-AGAGAAAGTAAGCTCTGCAGC-3'; antisense, 5'-CTGGCAGTGGTTTTGCTATTT-3' for the Nrf2 (H3K4Me3-binding site) gene. PCR of the $\beta$-actin promoter region across the $\mathrm{H} 3 \mathrm{~K} 4 \mathrm{Me} 3$ binding sites within -1541 to -1392 of the $\beta$-actin promoter was assessed: sense, 5'-GCCCTTAAGGCTGAGAAGGT-3' and antisense, 5'- GTAGAGACGGGGTTTCACCA-3' for the $\beta$-actin (H3K4Me3-binding site) gene. The PCR products were separated on $2 \%$ agarose gels, and DNA bands were visualized using the ImageJ program(NIH, Bethesda, MD, USA).

\section{Reactive oxygen species (ROS) assay}

Cells were seeded in 6 well plates at a density of $3 \times 10^{5}$ cells $/ \mathrm{ml}$. After $24 \mathrm{~h}$ of incubation at $37^{\circ} \mathrm{C}$, the cells were treated for $24 \mathrm{~h}$ with $140 \mu \mathrm{M}$ 5-FU. Cells were treated with $20 \mu \mathrm{M}$ dihydrorhodamine (DHR) 123, and the DHR123 fluorescence was detected using a flow cytometer (Becton Dickinson, Mountain View, CA, USA) and analyzed using Cell Quest software. For image analysis of the generation of intracellular ROS, cells were seeded on a coverslip-loaded 6-well plate at a density of 2 $\times 10^{5}$ cells $/ \mathrm{ml}$. After addition of $20 \mu \mathrm{M}$ DHR123 to each well and incubation for an additional $30 \mathrm{~min}$ at $37^{\circ} \mathrm{C}$, plates were washed with PBS, and stained cells were mounted onto a microscope slide in mounting medium (DAKO, Carpinteria, CA, USA). Microscopic images were analyzed using the Laser Scanning Microscope 5 PASCAL program (Carl Zeiss, Jena, Germany) on a confocal microscope. 


\section{Intracellular hydrogen peroxide $\left(\mathrm{H}_{2} \mathrm{O}_{2}\right)$ assay}

The DCF-DA method was used to detect the levels of intracellular $\mathrm{H}_{2} \mathrm{O}_{2}$. Cells were seeded in a 96 well plate at $2 \times 10^{4}$ cells $/ \mathrm{ml}$. Sixteen hours after plating, cells were treated with catalase (CAT, a specific scavenger of $\mathrm{H}_{2} \mathrm{O}_{2}$ ) at $0.5 \mathrm{U} / \mathrm{ml}$. After $48 \mathrm{~h}, 25 \mu \mathrm{M}$ of DCF-DA solution was added. After the addition of $25 \mu \mathrm{M}$ of DCF-DA solution for $10 \mathrm{~min}, 2^{\prime}, 7^{\prime}$-dichlorofluorescein fluorescence was detected using a Perkin Elmer LS-5B spectrofluorometer. Fluorescence readings were detected using a plate reader with exit/emission at $485 \mathrm{~nm} / 535 \mathrm{~nm}$.

\section{Intracellular superoxide anion $\left(\mathrm{O}_{2}^{-}\right)$assay}

To investigate the superoxide anion inside the cells, the fluorescent probe dihydroethidium (DHE) was used. DHE reacts primarily with $\mathrm{O}_{2}^{-}$to form an oxidized fluorescent product. After entering the cell, this probe is oxidized to ethidium [36]. The cells were seeded in a 96 well plate at $2 \times 10^{4}$ cells $/ \mathrm{ml}$. Sixteen hours after plating, cells were treated with superoxide anion dismutase (SOD, a specific scavenger of $\mathrm{O}_{2}^{-}$) at $30 \mathrm{U} / \mathrm{ml}$. After $48 \mathrm{~h}, 10 \mu \mathrm{M}$ DHE was added. The plate was incubated for $30 \mathrm{~min}$ in a dark condition. Fluorescence readings were detected using a plate reader with exit/emission at $510 \mathrm{~nm} / 595 \mathrm{~nm}$. The fluorescence was detected using a Perkin Elmer LS-5B spectrofluorometer.

\section{Intracellular hydroxyl radical (HO·) assay}

The fluorescent dye 3-(p-hydroxyl-phenyl) fluorescein (HPF) was used at a concentration of $5 \mu \mathrm{M}$ to assess the hydroxyl radical level inside the cells. Cells were seeded in 6 well plates at the density of $3 \times 10^{5}$ cells $/ \mathrm{ml}$. Sixteen hours after plating, cells were treated with dimethyl sulfoxide (DMSO), a hydroxyl radical scavenger, at a final concentration of $2 \%$. After $48 \mathrm{~h}$, cells were treated with $5 \mu \mathrm{M}$ of HPF in a dark condition, and the fluorescence was detected using a flow cytometer (Becton Dickinson, Mountain View, CA, USA) and analyzed by the Cell Quest software. Fluorescence readings were detected using a plate reader with exit/emission at $485 \mathrm{~nm} / 528 \mathrm{~nm}$.

\section{Statistical analysis}

All measurements were performed in triplicate, and values are expressed as the mean \pm the standard error of the mean (SEM). The results were examined using analysis of variance (ANOVA) and Tukey's test to determine pairwise differences. A $p<0.05$ was considered significant.

\section{ACKNOWLEDGMENTS}

This study was supported by a grant from the National R\&D Program for Cancer Control, Ministry for Health and Welfare, Republic of Korea (1120340).

\section{CONFLICTS OF INTEREST}

The authors declare no conflicts of interest.

\section{REFERENCES}

1. Shilatifard A. The COMPASS family of histone H3K4 methylases: mechanisms of regulation in development and disease pathogenesis. Annu Rev Biochem. 2012; 81:65-95.

2. Hubert A, Henderson JM Ross KG, Cowles MW, Torres J, Zayas RM. Epigenetic regulation of planarian stem cells by the SET1/MLL family of histone methyltransferases. Epigenetics. 2012; 8:79-91.

3. Ernst P, Vakoc CR. WRAD: enabler of the SET1-family of H3K4 methyltransferases. Brief Funct Genomics. 2012; 11:217-226.

4. Deplus R, Delatte B, Schwinn MK, Defrance M, Méndez J, Murphy N, Dawson MA, Volkmar M, Putmans P, Calonne E, Shih AH, Levine RL, Bernard O, et al. TET2 and TET3 regulate GlcNAcylation and $\mathrm{H} 3 \mathrm{~K} 4$ methylation through OGT and SET1/COMPASS. EMBO J. 2013; 32:645-655.

5. Bhutani N, Burns DM, Blau HM. DNA demethylation dynamics. Cell. 2011; 146:866-872.

6. Shi FT, Kim H, Lu W, He Q, Liu D, Goodell MA, Wan M, Songyang Z. Ten-eleven translocation 1 (Tet1) is regulated by O-linked $\mathrm{N}$-acetylglucosamine transferase (Ogt) for target gene repression in mouse embryonic stem cells. J Biol Chem. 2013; 288:20776-20784.

7. Fu X, Jin L, Wang X, Luo A, Hu J, Zheng X, Tsark WM, Riggs AD, Ku HT, Huang W. MicroRNA-26a targets ten eleven translocation enzymes and is regulated during pancreatic cell differentiation. Proc Natl Acad Sci USA. 2013; 110:17892-17897.

8. Kinney SR, Pradhan S. Ten eleven translocation enzymes and 5-hydroxymethylation in mammalian development and cancer. Adv Exp Med Biol. 2013; 754:57-79.

9. Vella P, Scelfo A, Jammula S, Chiacchiera F, Williams K, Cuomo A, Roberto A, Christensen J, Bonaldi T, Helin K, Pasini D. Tet proteins connect the O-linked $\mathrm{N}$-acetylglucosamine transferase Ogt to chromatin in embryonic stem cells. Mol Cell. 2013; 49:645-656.

10. Williams K, Christensen J, Pedersen MT, Johansen JV, Cloos PA, Rappsilber J, Helin K. TET1 and hydroxymethylcytosine in transcription and DNA methylation fidelity. Nature. 2011; 473:343-348.

11. Wu H, D'Alessio AC, Ito S, Xia K, Wang Z, Cui K, Zhao K, Sun YE, Zhang Y. Dual functions of Tet1 in transcriptional regulation in mouse embryonic stem cells. Nature. 2011; 473:389-393.

12. Niu Y, DesMarais TL, Tong Z, Yao Y, Costa M. Oxidative stress alters global histone modification and DNA methylation. Free Radic Biol Med. 2015; 82: 22-28.

13. Kang KA, Piao MJ, Kim KC, Kang HK, Chang WY, Park IC, Keum YS, Surh YJ, Hyun JW. Epigenetic modification of Nrf2 in 5-fluorouracil-resistant colon cancer cells: 
involvement of TET-dependent DNA demethylation. Cell Death Dis. 2014; 5:e1183.

14. Wilson AC, LaMarco K, Peterson MG, Herr W. The VP16 accessory protein $\mathrm{HCF}$ is a family of polypeptides processed from a large precursor protein. Cell. 1993, 74:115-125.

15. Yokoyama A, Wang Z, Wysocka J, Sanyal M, Aufiero DJ, Kitabayashi I, Herr W, Cleary ML. Leukemia proto-oncoprotein MLL forms a SET1-like histone methyltransferase complex with menin to regulate Hox gene expression. Mol Cell Biol. 2004; 24:5639-5649.

16. Lazarus MB, Jiang J, Kapuria V, Bhuiyan T, Janetzko J, Zandberg WF, Vocadlo DJ, Herr W, Walker S. HCF-1 is cleaved in the active site of O-GlcNAc transferase. Science. 2013; 342:1235-1239.

17. Ding X, Jiang W, Zhou P, Liu L, Wan X, Yuan X, Wang X, Chen M, Chen J, Yang J, Kong C, Li B, Peng C, et al. Mixed lineage leukemia 5 (MLL5) protein stability is cooperatively regulated by $\mathrm{O}-\mathrm{GlcNac}$ transferase (OGT) and ubiquitin specific protease 7 (USP7). PLoS One. 2015;10:e145023.

18. Hwang IT, Chung YM, Kim JJ, Chung JS, Kim BS, Kim HJ, Kim JS, Yoo YD. Drug resistance to 5-FU linked to reactive oxygen species modulator. Biochem Biophys Res Commun. 2007; 359:304-310.

19. Whetstine JR, Nottke A, Lan F, Huarte M, Smolikov S, Chen Z, Spooner E, Li E, Zhang G, Colaiacovo M, Shi Y. Reversal of histone lysine trimethylation by the JMJD2 family of histone demethylases. Cell. 2006; 125:467-481.

20. Hughes CM, Rozenblatt-Rosen O, Milne TA, Copeland TD, Levine SS, Lee JC, Hayes DN, Shanmugam KS, Bhattacharjee A, Biondi CA, Kay GF, Hayward NK, Hess $\mathrm{JL}$, et al. Menin associates with a trithorax family histone methyltransferase complex and with the hoxc8 locus. Mol Cell. 2004; 13:587-597.

21. Yokoyama A, Wang Z, Wysocka J, Sanyal M, Aufiero DJ, Kitabayashi I, Herr W, Cleary ML. Leukemia proto-oncoprotein MLL forms a SET1-like histone methyltransferase complex with menin to regulate Hox gene expression. Mol Cell Biol. 2004; 24:5639-5649.

22. Dou Y, Milne TA, Ruthenburg AJ, Lee S, Lee JW, Verdine GL, Allis CD, Roeder RG. Regulation of MLL1 H3K4 methyltransferase activity by its core components. Nat Struct Mol Biol. 2006; 13:713-719.

23. Lee JH, Tate CM, You JS, Skalnik DG. Identification and characterization of the human Set1B histone H3-Lys4 methyltransferase complex. J Biol Chem. 2007; 282:13419-13428.

24. Steward MM, Lee JS, O'Donovan A, Wyatt M, Bernstein BE, Shilatifard A. Molecular regulation of $\mathrm{H} 3 \mathrm{~K} 4$ trimethylation by ASH2L, a shared subunit of MLL complexes. Nat Struct Mol Biol. 2006; 13:852-854.

25. Crawford BD, Hess JL. MLL core components give the green light to histone methylation. ACS Chem Biol. 2006; $1: 495-498$

26. Cho YW, Hong $\mathrm{T}$, Hong S, Guo H, Yu H, Kim D, Guszczynski T, Dressler GR, Copeland TD, Kalkum M, Ge K. PTIP associates with MLL3- and MLL4- containing histone H3 lysine 4 methyltransferase complex. J Biol Chem. 2007; 282:20395-20406.

27. Lee MG, Villa R, Trojer P, Norman J, Yan KP, Reinberg D, Di Croce L, Shiekhattar R. Demethylation of H3K27 regulates polycomb recruitment and $\mathrm{H} 2 \mathrm{~A}$ ubiquitination. Science. 2007; 318:447-450.

28. Agger K, Cloos PA, Christensen J, Pasini D, Rose S, Rappsilber J, Issaeva I, Canaani E, Salcini AE, Helin K. UTX and JMJD3 are histone H3K27 demethylases involved in HOX gene regulation and development. Nature. 2007; 449:731-734.

29. Joshi AA, Struhl K. Eaf3 chromodomain interaction with methylated H3-K36 links histone deacetylation to Pol II elongation. Mol Cell. 2005; 20:971-978.

30. Capotosti F, Guernier S, Lammers F, Waridel P, Cai Y, Jin J, Conaway JW, Conaway RC, Herr W. O-GlcNAc transferase catalyzes site-specific proteolysis of HCF-1. Cell. 2011; 144:376-388.

31. Hanover JA, Krause MW, Love DC. Bittersweet memories: Linking metabolism to epigenetics through O-GlcNAcylation. Nat Rev Mol Cell Biol. 2012; 13: 312-321.

32. Lima VV, Rigsby CS, Hardy DM, Webb RC, Tostes RC. O-GlcNAcylation: a novel post-translational mechanism to alter vascular cellular signaling in health and disease: focus on hypertension. J Am Soc Hypertens. 2009; 3:374-387.

33. Love DC, Krause MW, Hanover JA. O-GlcNAc cycling: emerging roles in development and epigenetics. Semin. Cell Dev Biol. 2010; 21: 646-654.

34. Chen Q, Chen Y, Bian C, Fujiki R, Yu X. TET2 promotes histone O-GlcNAcylation during gene transcription. Nature. 2013; 493:561-564.

35. Jung GR, Kim KJ, Choi CH, Lee TB, Han SI, Han HK, Lim SC. Effect of betulinic acid on anticancer drug-resistant colon cancer cells. Basic Clin Pharmacol Toxicol. 2007; 101:277-285.

36. Carter WO, Narayanan PK, Robinson JP. Intracellular hydrogen peroxide and superoxide anion detection in endothelial cells. J Leukoc Biol. 1994; 55:253-258. 